\title{
Awards Program of the American Dairy Science Association ${ }^{\circledR}$
}

The annual Awards Program of the American Dairy Science Association and installation of new officers was held on July 13, 2010, at the Grand Hyatt, Denver, Colorado. Past President Phil Tong read the citations, and representatives of the donors presented the awards. The association greatly appreciates the continued generosity and support of the donors in presenting the annual awards to ADSA ${ }^{\circledR}$ members.

\section{Citation for Anil K. G. Kadegowda \\ Recipient of the 2010 Alltech Inc. Graduate Student Paper Publication Award}

The recipient of the 2010 Alltech Inc. Graduate Student Publication Award is Anil Kadegowda. Kadegowda is recognized for his paper "Identification of

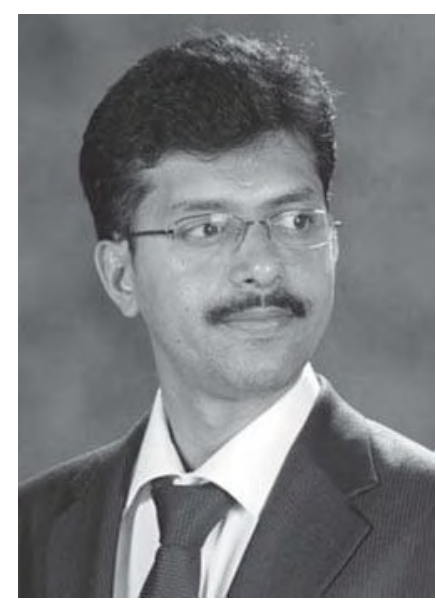
internal control genes for quantitative polymerase chain reaction in mammary tissue from lactating cows receiving lipid supplements," published in the May 2009 issue of the Journal of Dairy Science. This paper highlighted the discrepancies in the routinely used internal control genes and identified novel internal control genes for quantitative polymerase chain reaction (qPCR) normalization in studies with lactating dairy cows. Before the publication of this paper, there was no consensus on suitable internal control genes for studies of dietary lipid effects on ruminant mammary transcriptomes. Kadegowda demonstrated that the geometric average of MRPL39, UXT, and EIF3K is ideal for normalization of mammary qPCR data in studies involving lipid supplementation of dairy cows.

In 2008, Kadegowda received his $\mathrm{PhD}$ from the University of Maryland under the guidance of Richard Erdman for his thesis research on the role of dietary fatty acids in regulating milk fat synthesis in lactating dairy cows. His studies with dairy cows showed that the short- and medium-chain fatty acids might be limiting for milk fat synthesis and identified the potential

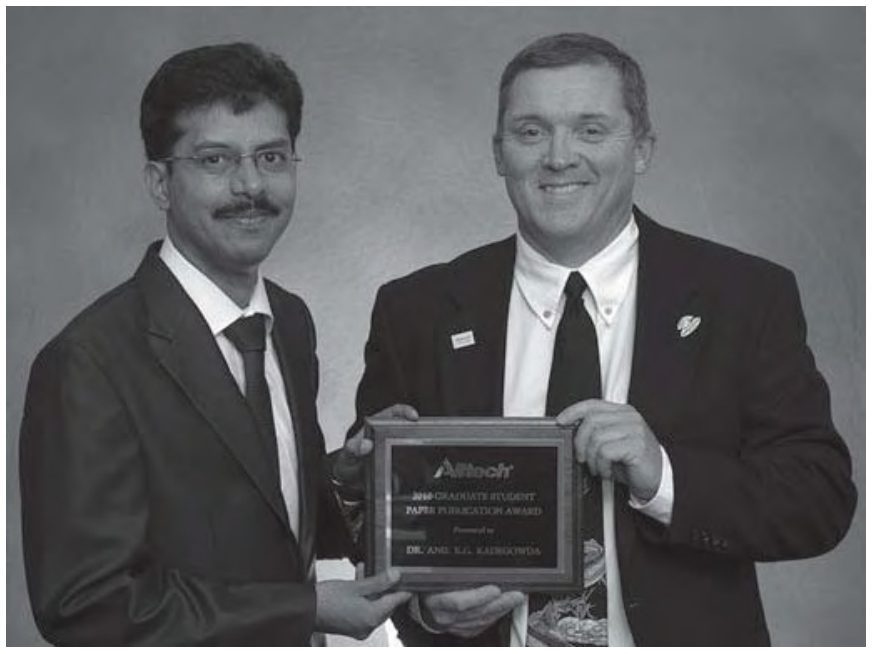

Anil Kadegowda (left) receives the 2010 Alltech Inc. Graduate Student Paper Publication Award from Alan Harrison, donor representative (right).

involvement of trans-7 18:1/trans-7,cis-9 conjugated linoleic acid in milk fat depression. His thesis research demonstrated the role of dietary fatty acids in regulating mammary lipogenic pathways, highlighting the complexity and multiple transcription factor involvement in milk fat synthesis.

Kadegowda received his BVSc from University of Agricultural Sciences, Bangalore, India, in 1998 and MVSc from Haryana Agricultural University, India, in 2000. From 2000 to 2004, he was a research associate at the National Institute of Animal Nutrition and Physiology, India, working with K. S. Ramachandra on developing technologies for utilizing alternate feed resources for livestock. He is the author or coauthor of 13 peer-reviewed publications and 12 abstracts presented at conferences. Currently, Kadegowda is a postdoctoral fellow in Ian Mather's laboratory, University of Maryland, and is working on the role of butyrophilin and xanthine dehydrogenase in milk lipid secretion.

\section{Citation for Michael Van Amburgh Recipient of the 2010 American Feed Industry Association Award}

Michael E. Van Amburgh is currently an associate professor at Cornell University with a $50 \%$ research and 50\% teaching appointment. Van Amburgh received his 
BS degree from The Ohio State University and his PhD degree from Cornell University. Van Amburgh is recognized nationally and internationally for his outstanding research contributions to

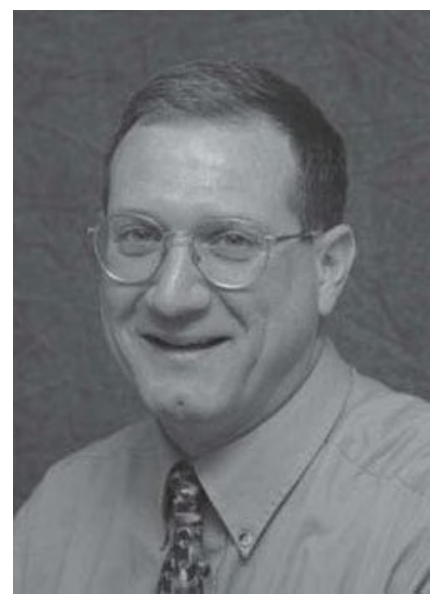
the dairy industry in the areas of growth and development of dairy replacement animals, ruminant nitrogen utilization during growth and lactation, and modeling feed chemistry and components present in dairy rations and comparing them with expected and actual growth and milk production data using the Cornell Net Carbohydrate and Proteins System (CNCPS).

Van Amburgh is best known for his research evaluating nutrient requirements of dairy replacement animals, starting at birth through lactation. Van Amburgh has investigated the endocrine and ontogenic control of several processes, including pubertal and mammary development. The mammary development research was groundbreaking in that it allowed the industry to reevaluate what was thought to be a problem (negative effects of nutrient intake on mammary development) and refocus an entire area of research. Van Amburgh's laboratory is continuing this work by looking at specific cells in the neonatal mam-

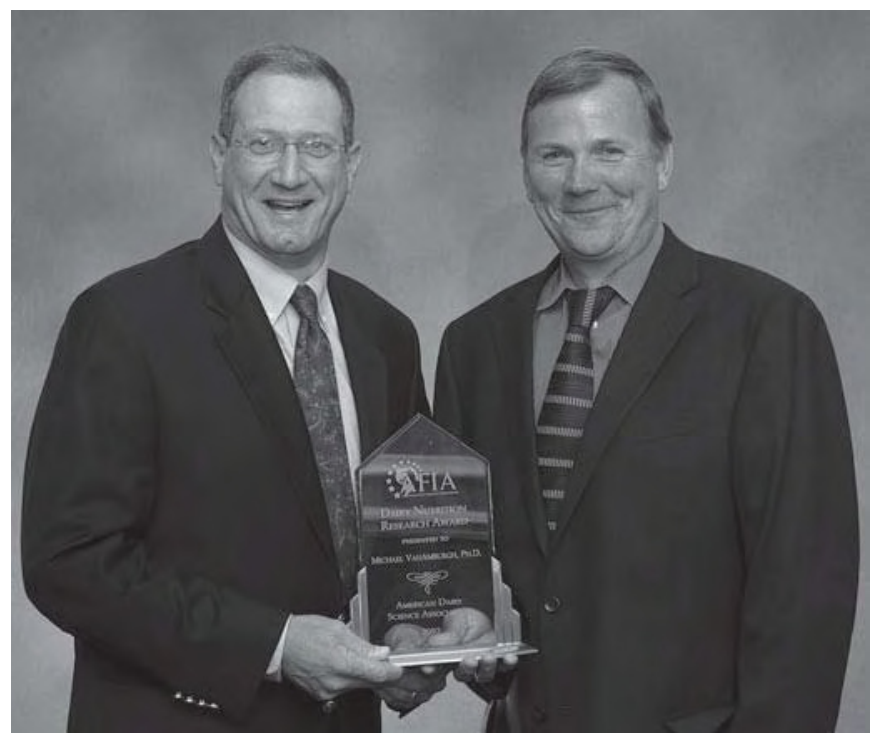

Michael Van Amburgh (left) receives the 2010 American Feed Industry Association Award from Tom Earleywine, donor representative (right). mary gland, and these cells appear to have stem-cell-like activity. Data analyzed to date suggest that increased nutrition early in life leads to either an increase in cell proliferation or programming that leads to increased milk production during lactation.

Van Amburgh also conducts modeling of feed chemistry and components present in dairy rations, comparing them with expected and actual growth and milk production data using the CNCPS. The CNCPS is dynamic in nature and has become a more powerful tool that other ration evaluators used for dairy cows. Van Amburgh and his research group are focused on continuous improvement of the model, with the intent that the biology of the cow matches the modeling within the software. This model is the one most used in the industry for building and evaluating dairy rations in the field.

Van Amburgh is currently conducting research on nitrogen utilization in lactating dairy cows. This area of research is needed because dairy producers are being pressured to reduce the environmental effect of their operations, and it is also a major way to reduce feed costs. As part of this research, Van Amburgh has used the CNCPS model, which is now more sensitive to nitrogen inputs and predictions of nitrogen use. Van Amburgh plans to further develop data sets to allow better parameterization and characterization of nitrogen utilization for application in the industry.

Van Amburgh has spent his career focusing on many relevant areas of dairy cattle nutrition research. Throughout his career, he has published 46 peerreviewed journal articles and numerous popular press and extension publications and has given many invited presentations. He has taken the research from the initial question to the answer and then to the field, ensuring it is implemented and used. I can think of no better recipient of the American Feed Industry Association award than Michael Van Amburgh.

\section{Citation for Barry Bradford Recipient of the 2010 Cargill Animal Nutrition Young Scientist Award}

Barry Bradford is the recipient of the 2010 Cargill Animal Nutrition Young Scientist Award. A native of Iowa, Bradford earned dual BS degrees in animal science and agricultural biochemistry at Iowa State University in 2002 and then went on to complete a PhD in dairy nutrition at Michigan State University.

Bradford joined the Kansas State University Department of Animal Sciences and Industry as an assistant professor specializing in dairy nutrition in September 2006. Bradford has quickly developed an innovative 
research program focused on alternative feedstuffs, transition cow health, and physiological regulation of carbohydrate and lipid metabolism.

The focus of much of

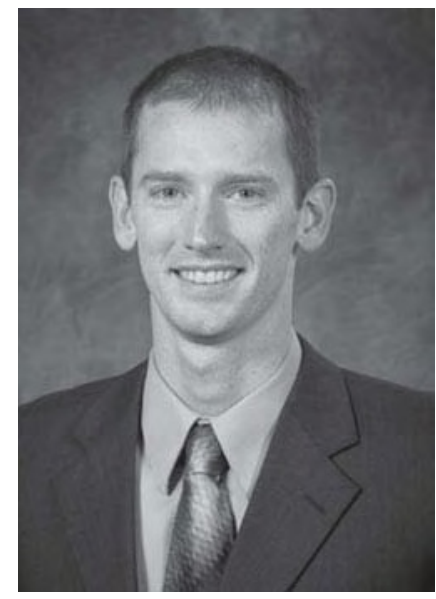

Bradford's research is how metabolism in dairy cows during the transition to lactation affects subsequent health and milk production. Bradford found that a high dose of encapsulated niacin was effective at decreasing plasma NEFA and ketone concentrations in the first 2 weeks after calving, but that it also depressed feed intake in multiparous cows in the days before calving. He then showed that niacin receptor mRNA and protein are found in liver, muscle, and nervous tissue in addition to adipose tissue of cattle, providing a potential explanation for intake depression by niacin. In a separate line of research, Bradford has pursued the hypothesis that inflammation is a root cause of metabolic disorders in the transition period. His initial work clearly demonstrated that lowlevel administration of an inflammatory mediator negatively affected liver metabolism and led to increased fat storage in the liver, providing the first causal evidence that inflammation can promote the development of fatty liver.

In addition to his basic research with health and nutrition of the periparturient dairy cow, Bradford has studied how to best incorporate feedstuffs such as

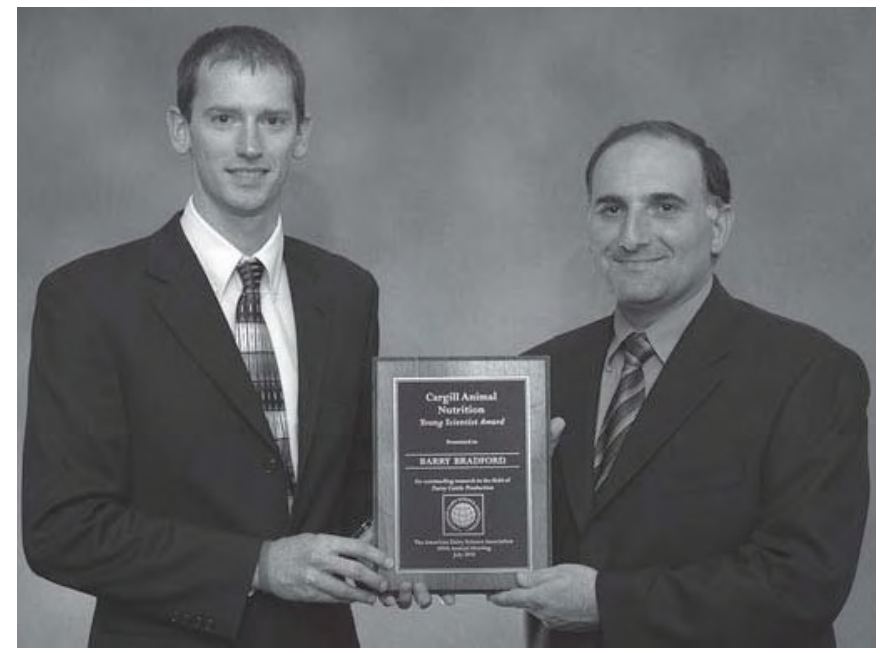

Barry Bradford (left) receives the 2010 Cargill Animal Nutrition Young Scientist Award from Guillermo Schroeder, donor representative (right). whole cottonseed, wet corn gluten feed, and molasses into the diets of lactating cows. His work has shown that dietary molasses can ameliorate some of the milk fat-depressing effects associated with the feeding of distillers grains. Bradford has also made contributions to our understanding of microbial effects on host physiology. By demonstrating that ruminal production of angiopoietin-like protein 4 is altered by diet fermentability, his work has suggested a novel model by which ruminal metabolism may alter postabsorptive lipid metabolism in ruminants.

Bradford's work has led to 19 peer-reviewed publications, 46 meeting abstracts, 28 extension and popular press articles, and 13 invited talks throughout North America. His research has been supported by more than $\$ 800,000$ in financial support, including a National Research Initiative Competitive Grant from the USDA National Institute of Food and Agriculture. Bradford currently advises $3 \mathrm{PhD}$ and $4 \mathrm{MS}$ students.

Bradford is also active in undergraduate teaching. He has taught a number of courses, including Principles of Feeding, Fundamentals of Nutrition, Dairy Nutrition, and portions of Physiology of Lactation, and he currently instructs over 150 students annually. He currently advises 40 undergraduates, many of whom are focused on dairy production. Bradford serves as an advisor to the Dairy Science Club and the Animal Sciences and Industry Graduate Student Association.

\section{Citation for David Mills Recipient of the 2010 Cargill Flavor Systems Food Specialties Award}

David Mills is a professor in the Department of Viticulture and Enology in the Robert Mondavi Institute for Wine and Food Sciences at the University of

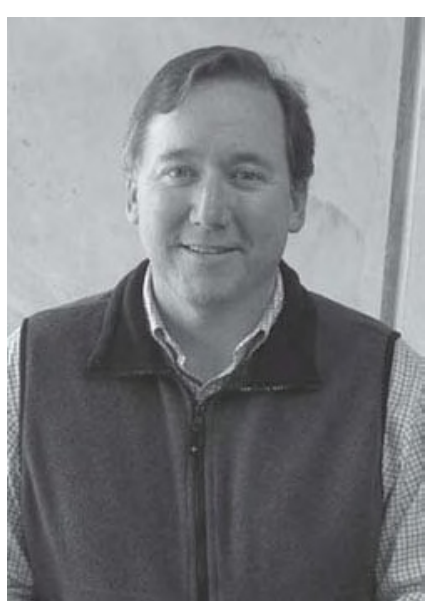
California at Davis. Mills has over 20 years of experience working in the area of food microbiology. As a faculty member at UC Davis, Mills's research has focused on the ecology and molecular biology of lactic acid bacteria (LAB) found in foods and in the intestine. This has involved analyses of the microbial ecology of various food and intestine environments and the development of genomics for the LAB field in general. In the last decade, Mills led the Lactic Acid Bacteria Genomics Consortium Project, 


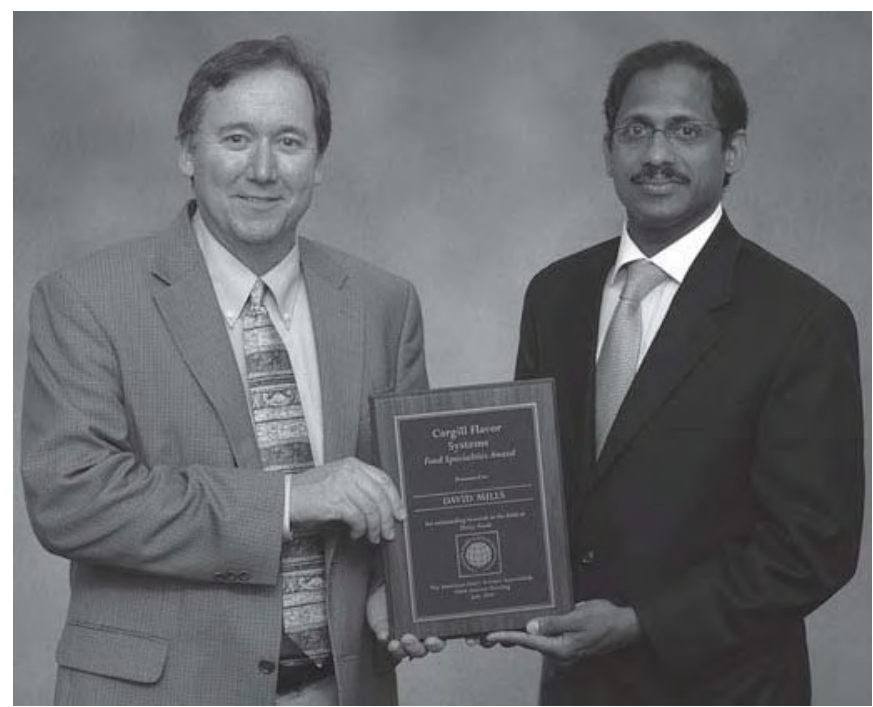

David Mills (left) receives the 2010 Cargill Flavor Systems Food Specialties Award from Sanjay Gummalla, donor representative (right).

which resulted in a seminal comparative analysis and release of key genome sequences of food-grade LAB and bifidobacteria. More recently with Bruce German and Carlito Lebrilla, Mills formed the UC Davis Functional Glycomics Program, which has become a very successful multidisciplinary effort to characterize the influence of milk glycans on intestinal health.

Mills served as Waksman Foundation Lecturer for the American Society for Microbiology (ASM) and currently is chair of the Food Microbiology Division of ASM. He has served on the editorial board of Applied and Environmental Microbiology and is currently an associate editor for Microbiology.

Mills obtained a BS in biochemistry from the University of Wisconsin-Madison, where he subsequently worked as a technician for John Markley. He obtained an MS degree in biochemistry with Michael Flickinger at the University of Minnesota in 1991, followed by a PhD in 1995 working with Gary Dunny and Larry McKay. After postdoctoral studies at North Carolina State University with Todd Klaenhammer, Mills took a faculty position at UC Davis.

\section{Citation for Kasipathy Kailasapathy Recipient of the 2010 Danisco International Dairy Science Award}

The 2010 winner of the Danisco International Dairy Science Award is Kasipathy (Kaila) Kailasapathy, associate professor in the School of Natural Sciences at the University of Western Sydney, Australia. Kailasapathy obtained his BS (honors) from the University of Peradeniya, Sri Lanka, MS (honors) from Obihiro
Chikusan University, Japan, and PhD from The Pennsylvania State University. He also completed an MBA at the University of Western Sydney, Australia. Kailas-

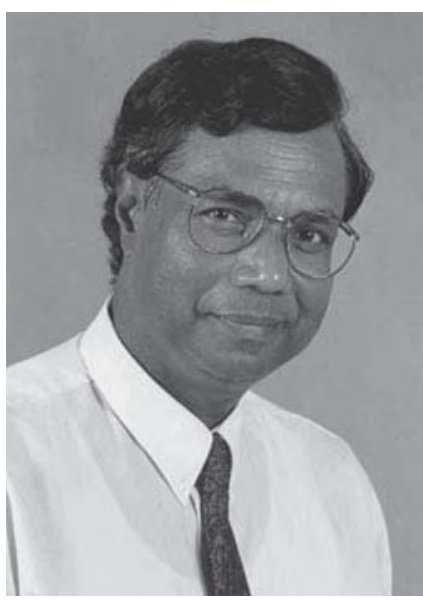
apathy leads an active research group on probiotics science and encapsulated functional dairy foods and process development, and he has published more than 100 refereed publications, 90 conference papers, including abstracts and proceedings, and 14 book chapters. He has been invited to deliver more than 10 addresses at microbiology, probiotic, dairy, and food conferences. Kailasapathy has supervised more than $30 \mathrm{MS}$ and $\mathrm{PhD}$ students. The main area of his research is probiotics and microencapsulation. His research has focused on three main themes including microencapsulation in dairy applications; improving enumeration techniques, viability, and functional efficacy of probiotic bacteria; and improving cheese yields. There are many challenges in incorporating probiotic cultures into milk products; probiotics fail to grow well in milk, lack the ability to compete with traditional starters, die during storage in acid dairy foods, are sensitive to oxygen and heat processing and cannot be added before pasteurization, and may produce acetic acid, which can affect product flavor. Furthermore,

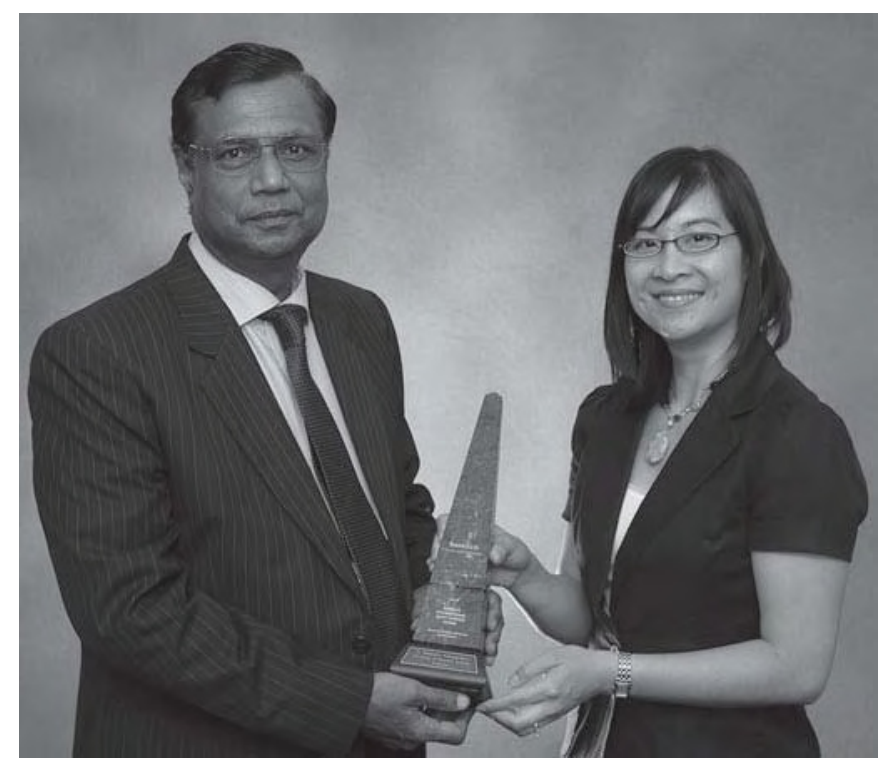

Kasipathy Kailasapathy (left) receives the 2010 Danisco International Dairy Science Award from Connie Sindelar, donor representative (right). 
consumers must be guaranteed a specified number of viable cells for the health effect to occur. Kailasapathy developed a microencapsulation system that uses safe and low-cost food polysaccharides as capsular wall materials to entrap bioactive components such as live probiotic bacterial cells, prebiotic substances, unstable enzymes, and water-soluble vitamins. Kailasapathy also developed an industrial microencapsulation prototype using a novel "falling film technology" to produce the large amounts of capsules needed for industrial applications. His research developed new methods to microencapsulate live probiotic bacterial cells and enhance their survival in dairy foods and in the gastrointestinal tract. Kailasapathy's work on microencapsulation also involved accelerated cheese ripening using encapsulated proteases and lipases. This has helped to reduce the maturation time and costs involved in long-term-maturation cheeses such as Cheddar. He has also developed techniques to encapsulate water-soluble vitamins such as folates (folate-fortified Cheddar cheese). Encapsulation will be critical to innovation in biofunctional dairy foods. Kailasapathy has been an executive councillor for the Dairy Industry Association of Australia; chair for the Probiotics and Gut Microbiology Special Interest Group, Australian Society of Microbiology; fellow of the Australian Institute of Food Science and Technology; and member of the International Bioencapsulation Group. He is a reviewer for most international dairy and food science journals and several international funding authorities. Kailasapathy has a keen interest in graduate education in dairy and food science and has been the graduate coordinator at the Centre for Plant and Food Science, University of Western Sydney. The 2010 Danisco International Dairy Science Award is awarded to Kaila Kailasapathy in recognition of his outstanding accomplishments in dairy science and his internationally recognized expertise in the area of probiotics and microencapsulation in dairy foods.

\section{Citation for Leo Timms Recipient of the 2010 DeLaval Dairy Extension Award}

Leo Timms is professor of animal science and veterinary diagnostics and production animal medicine and is extension dairy specialist at Iowa State University. Timms received a BS in 1978 from Cornell University with a double major in animal science and agricultural engineering. Following a two-year management role in a 400-cow New York dairy, he received his MS in 1982 and a PhD in 1984 from the University of WisconsinMadison. After graduation, Timms began his extension career as assistant professor and extension dairy specialist at Iowa State University. He currently holds the rank of professor with a split appointment between animal science and veterinary medicine.

Timms has developed an internationally recognized extension program in dairy

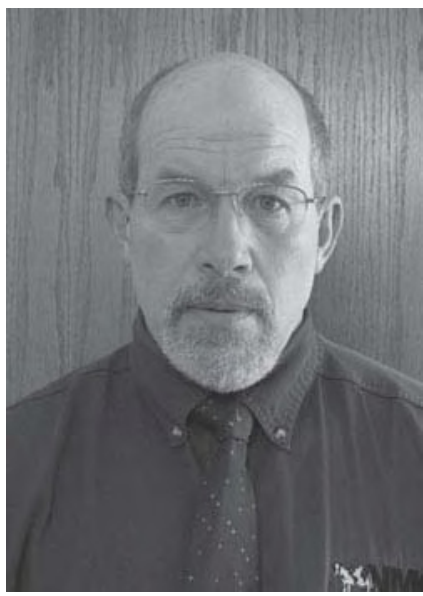
physiology, with particular emphasis on milk quality and mastitis, reproduction, and dairy records. He has melded his novel work in diagnostics, prevention, and therapy strategies in dry and transition cow mastitis into successful milk quality programs and techniques adopted worldwide. Timms has made outstanding contributions both individually and collaboratively in extension, technology transfer, and applied research related to dairy management and the dairy industry. In addition to dairy producers, Timms has committed himself to training and involvement with the veterinary community and youth.

Timms's novel research on developing dry cow sealants led to synthetic skin technologies that have been patented, commercialized, and used around the world. Marketing surveys in 2009 by Hoard's Dairyman showed a $43 \%$ North American herd adoption rate of sealant technologies for mastitis prevention in dry and transition cows. His collaborative work on validating the CMT test at calving has been adopted industry wide. He spearheaded a national effort in his regional research and extension project group to evaluate heifer

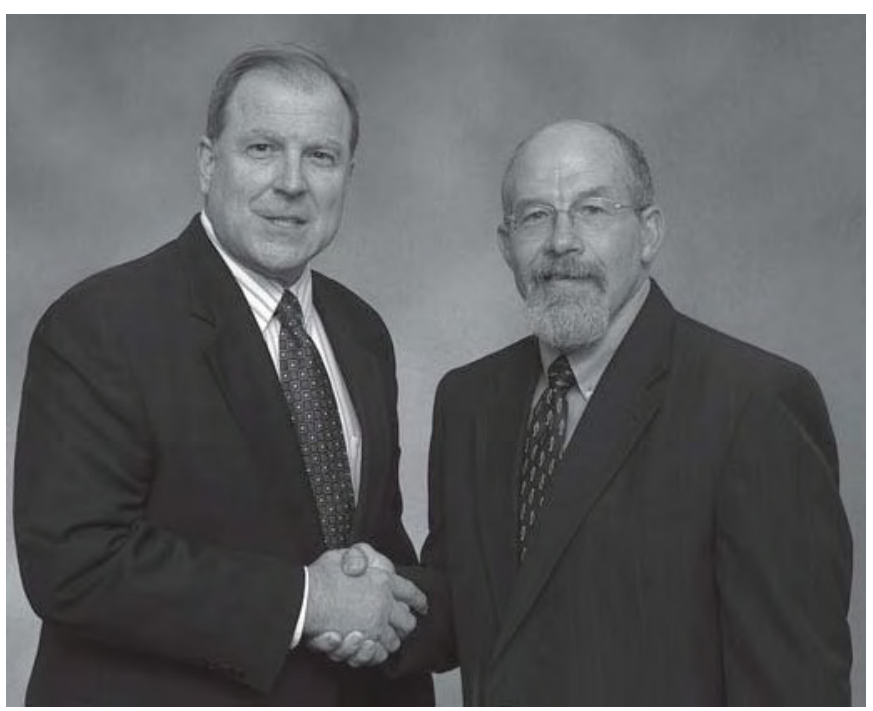

Leo Timms (right) receives the 2010 DeLaval Dairy Extension Award from Wyatt Smith, donor representative (left). 
mastitis management prior to first parturition and has co-published in this area, with the group demonstrating a $90 \%$ reduction in infection and mixed results on milk production.

Timms's work in sealant technology has resulted in seven patents. He has received over $\$ 250,000$ in grants and contracts as principal investigator, $\$ 463,000$ as a co-principal investigator, and $\$ 63,000$ in unrestricted gifts. Timms has authored or coauthored 21 refereed journal articles, 89 abstracts, 116 technical reports and symposia and conference proceedings, 66 ISU research reports, 161 extension publications, 49 newsletter articles, 94 popular press articles, and 100 video or computer educational presentations and tools, and he has given 500 invited presentations. He has served on 12 editorial boards and panels.

Besides his work in the United States, Timms has been actively involved in the international community, serving as research mentor, conducting international short courses, and hosting scientists from around the globe.

Timms has been an active member in ADSA for nearly 30 years, serving on many national and regional ADSA program committees, including chair of the Production Division Council and 2009 JAM program chair. In addition, he has served in presidential leadership roles in the National Mastitis Council, Midwest ADSA, and the Iowa Association for Food Protection. Timms was a founding member of Teat Club International, an international committee of 10 experts who developed a standardized teat health scoring and education system.

\section{Citation for Peter Spike Recipient of the 2010 Hoard's Dairyman Youth Development Award}

Peter Spike has a proven record of commitment and dedication to the development of young people through 4-H, FFA, and collegiate dairy activities. Throughout

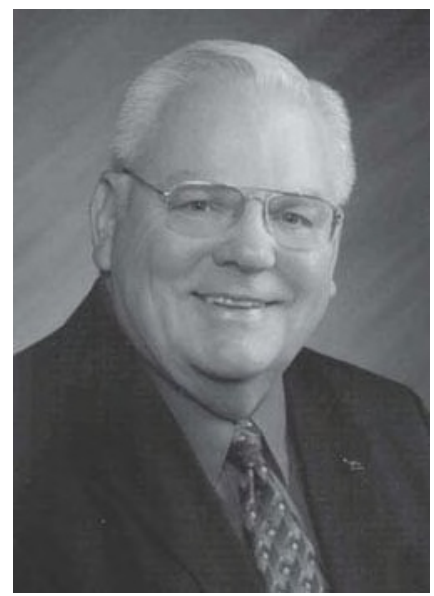
his career, Spike has had a profound effect on youth via his teaching, mentoring, and genuine caring to help them reach their goals. Many people in the dairy industry and beyond can attribute their successful careers to his tutorship. Spike's unique abilities and gentle guidance have touched the lives of countless youth, not only in Ohio but throughout the United States.

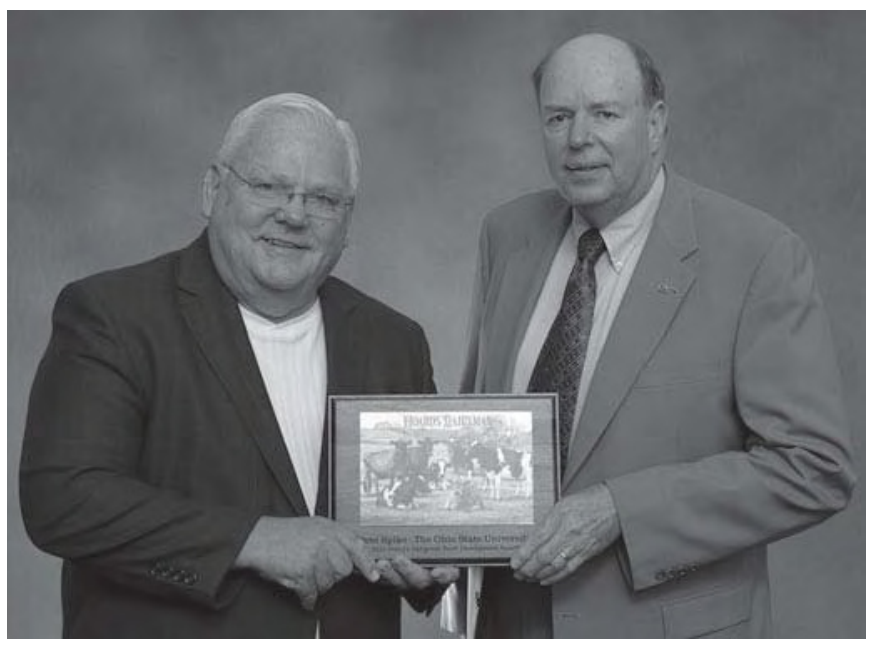

Peter Spike (left) receives the 2010 Hoard's Dairyman Youth Development Award from Steve Larson, donor representative (right).

Following his PhD degree, Spike worked for five years as extension dairy specialist at Michigan State University, two years as manager and partner of a Michigan dairy, and the remainder of his career in academia in Extension Dairy at The Ohio State University. He is an outstanding judge of dairy cattle and loves to teach this skill to youth of all ages. Spike served as past coach of the Ohio 4-H and The Ohio State University Dairy Judging Teams. Under his leadership, two teams won the National 4-H Dairy Judging Contest and fifteen 4-H teams placed in the top five. In addition, one team won the National Collegiate Dairy Judging Contest, and seven teams ranked in the top five.

In 1978, Spike started and coordinated the Ohio 4-H Dairy Quiz Bowl, and in 1980 he was instrumental in initiating the first Invitational 4-H Dairy Quiz Bowl Contest held at the North American International Livestock Exposition. He was senior coordinator of this contest for 26 years and continues to serve as co-coordinator in his retirement. During the 30-year span of this nationally recognized educational activity, over 2,300 youth from 32 states have participated and enhanced their knowledge and interest in the dairy industry.

Spike is actively involved in the National FFA Dairy Cattle Career Development Event, serving as official judge from 1982 to present, and he was on the Advisory Committee and was coordinator of written materials for the event through 2004. His philosophy is that all youth are winners; their experiences and interaction with other youth are first and foremost and winning is a distant second to the life skills they acquire.

As advisor of the Buckeye Dairy Club from 1981 to 2004, Spike provided leadership to club members and gave them the opportunity to hone their skills in cattle selection, fitting, and merchandizing by conduct- 
ing club-sponsored dairy consignment sales. Students also benefited from Spike's willingness to travel with them to study the dairy industry in other states and countries. Spike has spent countless hours interacting with students, serving as academic advisor and advisor to the Midwest and National ADSA Student Affiliate Division.

Spike has received numerous awards and recognition, but he remains a humble man, a team player who shares his time and expertise without wanting self-recognition. His reward is to see the merits of his leadership live on in the lives of those he has touched. These achievements and his commitment to youth across the country make Peter Spike a very deserving recipient of the Hoard's Dairyman Youth Development Award.

\section{Citation for Yves Pouliot Recipient of the 2010 International Dairy Foods Association Research Award in Dairy Foods Processing}

Yves Pouliot graduated from Université Laval in 1987 with a $\mathrm{PhD}$ in food science and technology. His $\mathrm{PhD}$ thesis titled "Contribution of milk salt balance

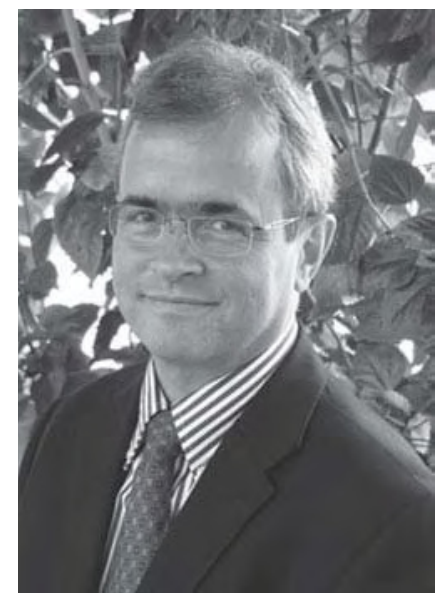
on the heat stability of milk" was cosupervised by Marcel Boulet and Paul Paquin. In 1985, he spent six months at the Hannah Research Institute under the supervision of D. G. Dalgleish, where he developed a keen interest in milk proteins and their processing. Pouliot started as research associate for the Center for Science and Technology Research (STELA) dairy research group in 1988 and got his first contract at Université Laval as assistant professor in 1990 and full professor in 1995. He has served on several occasions as director of the prestigious STELA group. He has also had business experience being a cofounder and research and development director for Advitech Solutions Inc., a company that produces milk peptides. His current position is that of director of the Institute of Nutraceuticals and Functional Foods, where he began as scientific director in 2005 and has been director since May 2008. This institute represents a most important group of a total of 38 regular members, 29 associates, and 2 honorary members from Quebec research institutions recognized throughout Canada.

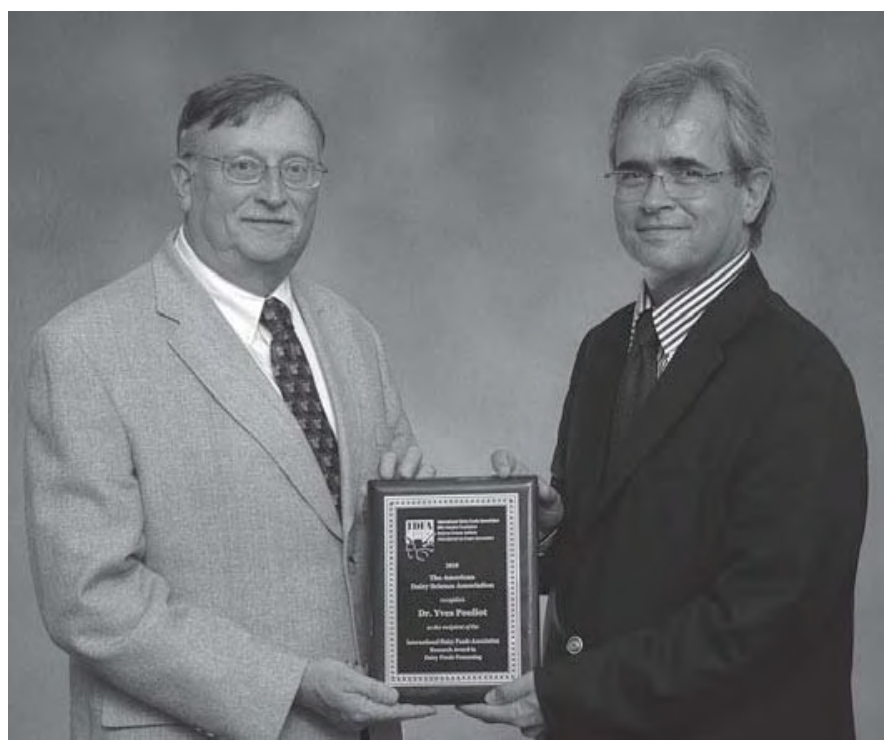

Yves Pouliot (right) receives the 2010 International Dairy Foods Association Research Award in Dairy Foods Processing from Dave McCoy, donor representative (left).

During his career he has demonstrated excellence in research and teaching and as an entrepreneur. He has authored and coauthored more than 75 peer-reviewed papers that accredit him as a world authority on milk protein fractionation, milk processing, and milk peptides production and separation by nanofiltration. As a professor at Université Laval, he is well regarded by undergraduate and graduate students. He has advised more than 30 graduate students on MS and $\mathrm{PhD}$ programs, in addition to being a mentor to many other students within the university. His students are consistently participating in national and international scientific gatherings and are usually doing outstanding work in graduate and undergraduate paper competitions. The most significant contribution from Pouliot is his research program on the development of bioactives from milk. The establishment of a research and development technological platform (during his involvement at Advitech) on the development of bioactive peptides from milk has led Pouliot to work in close collaboration with the major protein-based ingredients manufacturers worldwide. The development of a dairy-based bioactive ingredient, enriched in growth factors, for the treatment of psoriasis is one of his main achievements. He is a food scientist who has been devoting most of his research to milk chemistry and dairy processing. From the very beginning of his career, he focused on membrane separation processes applied to dairy fluids. His focus has been the production and separation of whey bioactive peptides, buttermilk minor components in the development of nutraceuticals from whey and 
buttermilk. The most recent research topic for which he developed a research program is the separation of milk growth factors for the preparation of nutraceuticals.

Pouliot now dedicates his efforts in the Institute of Nutraceuticals and Functional Foods, where the entire research program is focused on the complex interactions between foods, food components, nutrition, and health. The Institute of Nutraceuticals and Functional Foods conducts an innovative and multidisciplinary research program that supports the development of safe and efficient food products to improve health and prevent chronic diseases.

\section{Citation for Wilson Mattos Recipient of the 2010 International Dairy Production Award}

Wilson Mattos received his BS degree in agriculture from the University of São Paulo, Brazil, in 1970 and his MS and $\mathrm{PhD}$ degrees in dairy science from The Ohio State University in

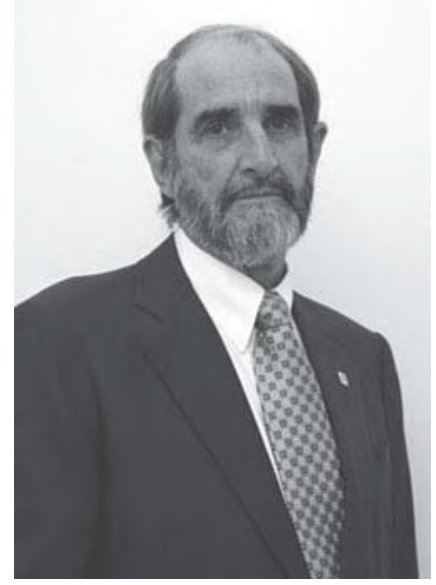
1973 and 1976, respectively. Since then he has been professor of animal science at the University of São Paulo, Piracicaba campus (ESALQ). Since his appointment, he has taught undergraduate and graduate courses in dairy cattle production, animal and ruminant nutrition, and metabolism of lipids and carbohydrates. He has supervised $28 \mathrm{MS}$ and 9 $\mathrm{PhD}$ (begun in 1998) students and has served on graduate exam committees for $81 \mathrm{MS}$ and $64 \mathrm{PhD}$ students in seven Brazilian states. He has served continuously as head of the Ruminant Nutrition Laboratory. He introduced to Brazil the detergent fiber analysis system for forages, led the development and application of recombinant bST in dairy herds, and introduced the Cornell Net Carbohydrate and Protein modeling systems to Brazilian dairy management. He served a period as department head and repeatedly on numerous department, college, and university committees. He has served on 30 faculty search committees for state and federal universities in five Brazilian states, as faculty representative to the university board of trustees, as college representative to a five-member national committee to recommend federal dairy research programs, and as consultant to the Brazilian government for graduate education and animal science research programs.

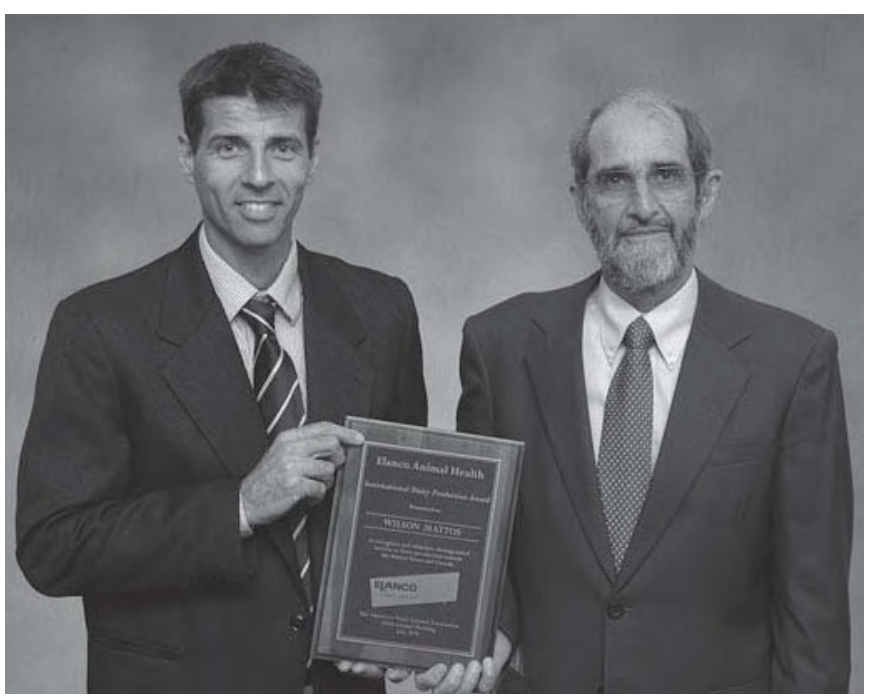

Wilson Mattos (right) receives the 2010 International Dairy Production Award from Jose Correia de Simas, donor representative (left).

In February 2009, he was appointed mayor of ESALQ by the president of the university. In addition to the duties of provost, this position includes responsibility for the staff and physical plant.

Wilson Mattos has been recognized with a Kellogg Foundation Fellowship to Texas A\&M, was named 2000 distinguished faculty member by his peers, and has served as president of the Brazilian Society of Animal Science. He was vice chair and executive secretary for the XIX International Grassland Congress hosted by Brazil. He has been recognized with the International Award from The Ohio State University College of Food, Agricultural and Environmental Sciences.

Wilson Mattos has published 28 peer-reviewed papers in both Portuguese and English, 16 reviews presented at symposia, 34 extension papers, more than 50 abstracts, and 9 book chapters and has edited 5 books.

Through all these activities, he has provided leadership of the highest quality. With specific evidence of leadership in the dairy industry, his coordination and leadership of Brazilian dairy farmers on trips to numerous countries, visiting not only productive farms, but also leading research institutions and commercial business related to the dairy industry, have been highly effective. All this has brought Brazil from the dark ages of dairying to a position of leadership in South America and has made Brazil a recognized world participant in animal research.

\section{Citation for Kent Weigel \\ Recipient of the 2010 J. L. Lush Award in Animal Breeding}

The winner of the J. L. Lush Award in Animal Breeding is Kent A. Weigel. Weigel has held the posi- 
tions of senior research associate at the Holstein Association from 1992 to 1995; research scientist at the University of Wisconsin (UW-Madison); genetic direc-

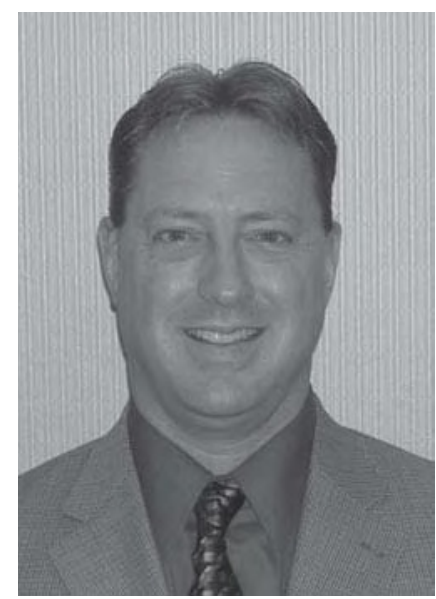
tor at World-Wide Sires from 1995 to 2001; and assistant, associate, and full professor of dairy science at UW-Madison from 2001 to the present. In 2003, he was honored with the ADSA Foundation Scholar Award and the ADSA Outstanding Young Scientist Award. In 2005, Weigel received the Pound Research Award from the College of Agricultural and Life Sciences, UW-Madison.

An exceptionally productive scientist, Weigel is recognized nationally and internationally as a leading specialist in dairy cattle genetics. He has achieved a high profile as a writer, invited speaker, and contributor to scientific and industry conferences. Since 2003 he has been invited to present symposium papers at the ADSA conference 4 times, other national conferences 10 times, and regional conferences 3 times. In addition, the European Association for Animal Production and four other international (in Norway, Germany, Ireland, and Tunisia) scientific conferences have invited presentations on his research. His resume also lists a large number of presentations to nontechnical audiences. His presentations are characterized by creativity and clarity

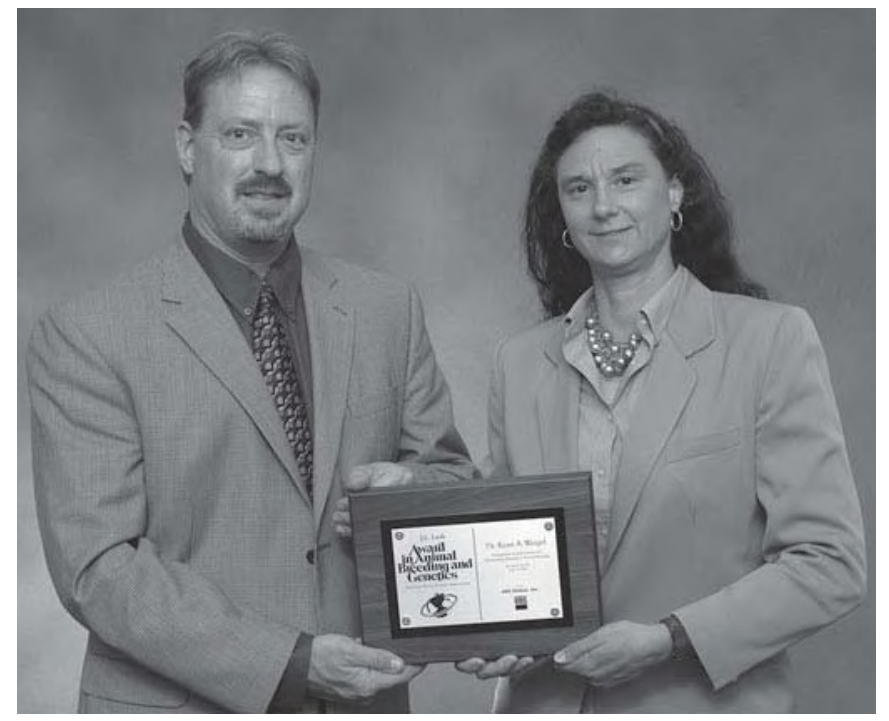

Kent Weigel (left) receives the 2010 J. L. Lush Award in Animal Breeding from Marjorie Faust, donor representative (right). and are well illustrated. He communicates effectively with scientific and nonscientific audiences.

Weigel has been author or coauthor of 65 journal articles since 2003. His subject matter with multiple publications has included reproduction and fertility, longevity, health traits, international genetic evaluation, sexed semen technology, genomic studies, calving traits, inbreeding depression, and crossbreeding. Five other subjects are represented by one article each: milking time, conformation, genotype-by-environment interaction, software development, and intellectual property. These topics represent most of the important contemporary issues in dairy cattle improvement.

In a field known for its modest research funding resources, Weigel has been exceptionally successful in attracting funding. Since 2003 he has been awarded a total of $\$ 1,880,258$ in grants as the sole or principal investigator. More than $80 \%$ of these funds were from public sources and nearly $20 \%$ were from industry. Remarkably, $81 \%$ of this support has been from extramural sources, with the balance coming from intramural sources. He was a co-investigator for other projects that total $\$ 1,435,060$ since 2003. In surveying Weigel's research, his nominator, George Shook, was most impressed by five attributes that appeared consistently in his studies. 1) His research program has been exceptionally productive. 2) His research topics represent the leading edge of contemporary issues in dairy cattle improvement, and these have evolved as the science has advanced. 3) He consistently uses the most up-to-date methods of statistical analysis. Examples include the use of threshold models for binary traits and survival or failure time analysis for herd-life and pregnancy traits. 4) $\mathrm{He}$ is resourceful in identifying novel data sources for genetic analysis. The main, but not only, example is his study of health traits. He consistently secures large, comprehensive databases for his studies. 5) His research approaches are nearly always novel and forward-looking. Weigel has attained a leadership position among researchers in animal breeding and genetics. His research is characterized by relevance, originality, and innovation. He identifies problems that are important to the industry, uses advanced research methods to develop solutions, and works to accomplish implementation of the solutions through active outreach efforts. He communicates his research results consistently and effectively to scientists, producers, and industry specialists.

\section{Citation for Peter Hansen Recipient of the 2010 Land O' Lakes Inc. Award}

Boyhood experiences on his cousin's farm in Ireland convinced Pete Hansen that a career working with 
livestock would be a rewarding one. Hansen received his BS degree in agricultural sciences in 1978 from the University of Illinois and his MS and PhD degrees

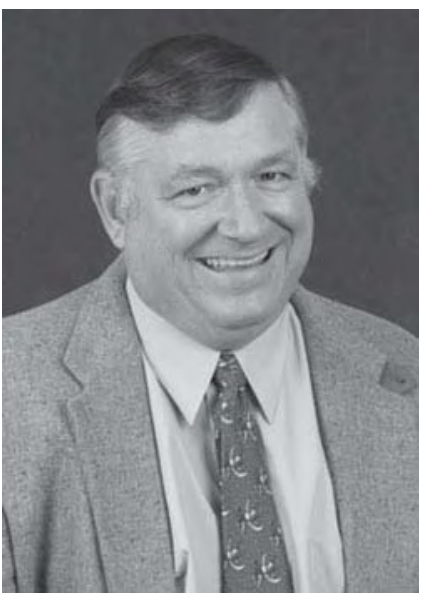

from the EndocrinologyReproductive Biology Program at the University of Wisconsin-Madison in 1980 and 1983, respectively. After completing postdoctoral training at the University of Florida, Hansen joined the faculty at Florida in 1984. He spent time on sabbatical leave at the University of Guelph in 1993 and currently holds the title of L. E. "Red" Larson Professor in the Department of Animal Sciences at the University of Florida.

Hansen's research interests have been focused on two major areas. One thrust is directed toward the improvement of fertility in dairy cows exposed to heat stress. This research has been concentrated on identifying the cellular and molecular consequences of exposure of preimplantation embryos to heat shock, and the identification of biochemical mechanisms to limit the deleterious effects of heat shock. Research is also underway to develop a practical embryo transfer program for improving fertility of heat-stressed cows based on production of in vitro-produced embryos. A second research thrust has been directed toward understanding the regulation of uterine immune function during pregnancy by the conceptus and maternal hormones. In addition to his research efforts, Hansen teaches courses

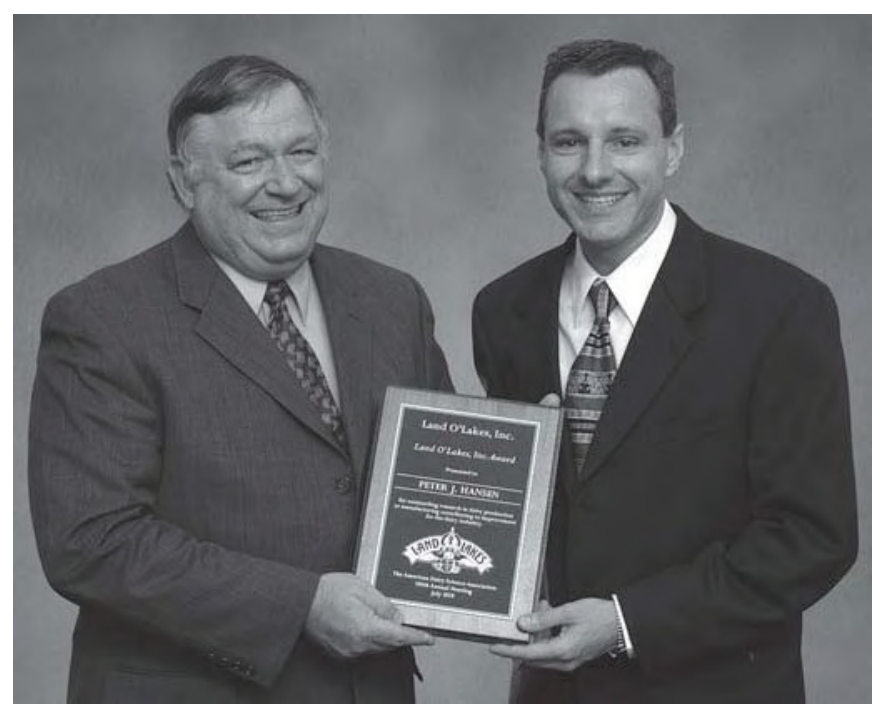

Peter Hansen (left) receives the 2010 Land O'Lakes Award from Tom Glenn, donor representative (right). in reproductive biology and environmental physiology and maintains several Web sites including one called the Dairy Reproduction Cookbook, which is designed to provide producers with practical information on reproductive management.

During his career, Hansen has published more than 220 refereed publications and 14 book chapters and has presented more than 100 invited lectures in a variety of national and international venues. Awards for his research include the Agway Inc. Young Scientist Award (1991) and the Pharmacia and Upjohn Physiology Award (1997) from ADSA; the Young Animal Scientist Award (1994) and Physiology and Endocrinology Award (2003) from the American Society of Animal Science; and the J. Christian Herr Research Award from the American Society for Reproductive Immunology (2000).

Hansen has been fortunate to be involved in the affairs of ADSA for many years. In addition to serving on various committees, he served as editor (1996-1998) and senior editor (1999-2000) of the Physiology and Management Section of the Journal of Dairy Science and has been the editor of the Invited Reviews section of the journal since 2003. Hansen also served as chair of the Journal Management Committee from 2002 to 2003 and is currently on the board of trustees of the ADSA Foundation.

\section{Citation for Michael Van Amburgh Recipient of the 2010 Land O'Lakes, Purina Feed LLC Teaching Award in Dairy Production}

Michael Van Amburgh has an extraordinary passion for teaching and an impressive ability to integrate research results, classroom facts, and biological concepts

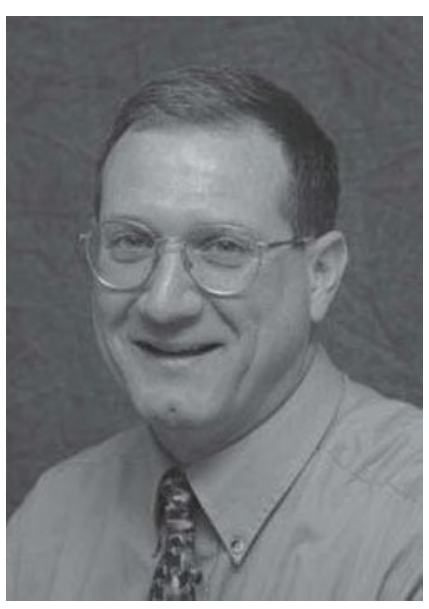
into application for realworld farm situations. Consequently, students taking his courses gain knowledge as well as the ability to think about and apply this knowledge. He is a good listener and plays a critical role in the personal growth and development of students. He advises over 50 undergraduates, and his advisees point to Mike's passion and effectiveness as a teacher but they also describe him in terms such as mentor, advisor, friend, and confidant. Van Amburgh has developed a senior level course in advanced dairy nutrition (Animal Science 4110, Inte- 


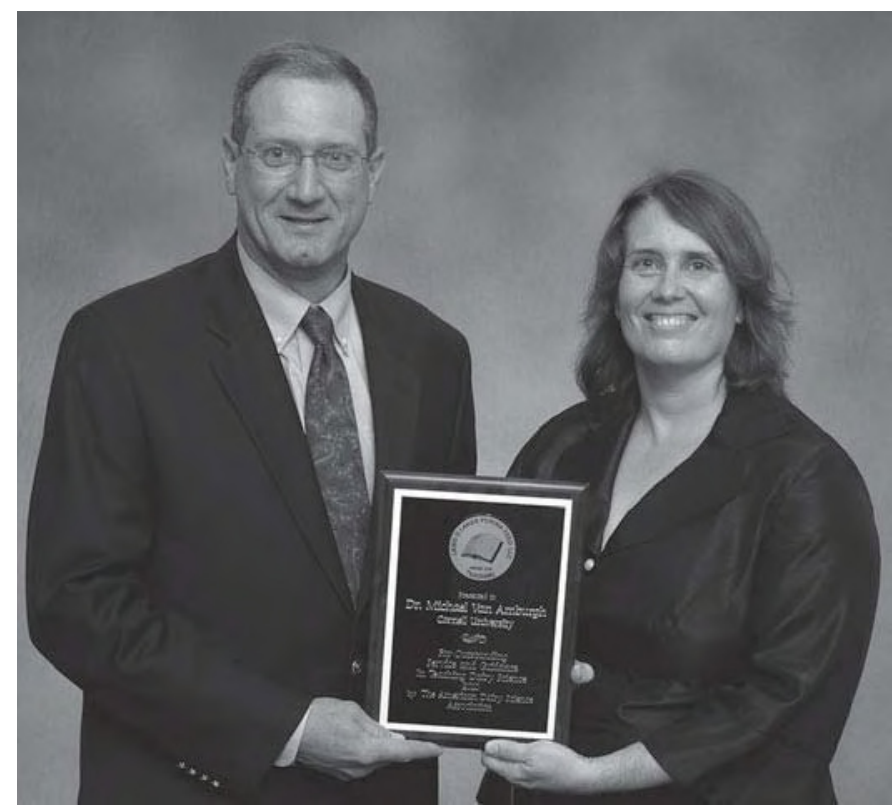

Michael Van Amburgh (left) receives the 2010 Land O'Lakes Purina Feed LLC Teaching Award in Dairy Production from Cindie Luhman, donor representative (right).

grated Cattle Nutrition) and has taught this course for the past 14 years with an average enrollment of approximately 45 students. This is considered the capstone course for any student who is interested in field application of fundamental nutrition concepts and nutritional management principles. The course is based on both classical and contemporary nutrition and management topics and includes using local dairy herds as case studies. It reinforces the concepts and principles through application of the Cornell Net Carbohydrate and Protein System (CNCPS). Furthermore, Van Amburgh works extensively with the Cornell Dairy Fellows Program, teaches three to four additional courses a year, such as Whole Farm Nutrient Management, an introductory animal science course focused on integrating animal physiology with contemporary management systems, and has developed an international study program where students interested in the dairy industry travel to other countries to learn about international agricultural policies, dairy production and products, and different cultures. The international experiences have become a significant and important learning activity for the Cornell dairy students and an integral component of the dairy production teaching program. In the past 14 years, more than 600 students have participated in these trips. To give some indication of the popularity of the international experience, 95 undergraduate students participated in an 11-day trip to Italy in 2006 to study the Italian dairy, food, and agriculture industries. Students participated in work- shops and hands-on activities involving the production of major regional cheeses such as Parmigiano Reggiano and Grana Padano, along with learning about the wine, meat, and olive industries. The students participated in sessions concerning EU trade policy, DOP designation (Protected Denomination of Origin), and current farm profitability with dairy producers, policy makers, and other industry professionals.

Van Amburgh also provides leadership in the Department and College in curriculum development and addressing curriculum issues through his service on the College and Department Curriculum committees. Currently, he is working with colleagues in restructuring the Department of Animal Science's course offerings in an attempt to address changing student needs and faculty expertise and interests. Mike is an active member of the regional and national Dairy Challenge boards. In addition, he coaches the Cornell Dairy Challenge team and manages to maintain an active research program.

\section{Citation for Stephanie Clark Recipient of the 2010 Kraft Foods Teaching Award in Dairy Science}

Stephanie Clark earned her BS in animal science from Cornell University (Ithaca, New York) in 1990 and con-

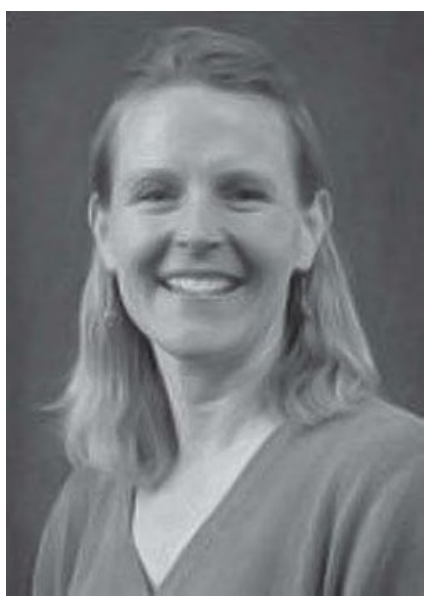
tinued to an MS in food science, which she earned in 1993. Clark earned her $\mathrm{PhD}$ in food science from Cornell University in 1997, and she joined the faculty at Washington State University (WSU) in January 1998. She earned tenure and was promoted to associate professor in 2004. Clark joined the faculty of Iowa State University (ISU) in August 2009 and serves as the associate director of the ISU Midwest Dairy Foods Research Center, where she oversees the ISU-associated dairy research component of this threeinstitution center.

One of Clark's research goals is to bridge gaps among important food quality and human health issues associated with dairy foods, specifically sensory quality, shelf life, consumer acceptability, probiotic bacteria, lactose maldigestion, and gut health. Her research has been presented in more than 40 peer-reviewed publications and more than 50 posters and presentations. Clark also interacts with the dairy industry throughout the world 


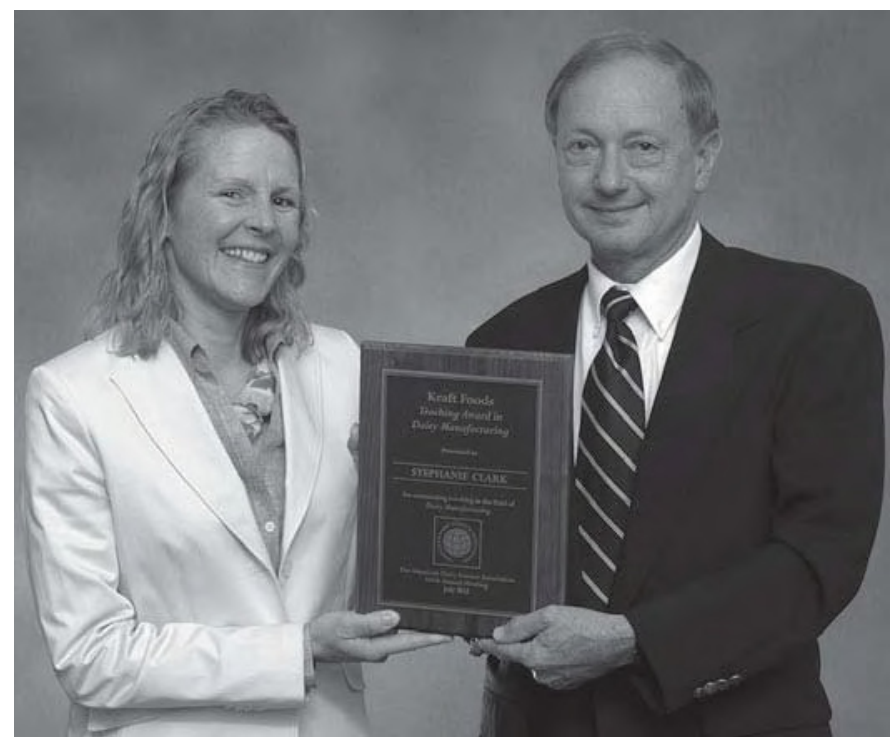

Stephanie Clark (left) receives the 2010 Kraft Foods Teaching Award in Dairy Science from Jim Moran, donor representative (right).

by conducting training in cheesemaking, sensory evaluation, and food safety and through troubleshooting quality issues.

Clark taught several food science courses at WSU, including Evaluation of Dairy Products I and II, Graduate Oral Seminar, Graduate Written Seminar, and Dairy Products. At ISU, she teaches Dairy Products Evaluation, Undergraduate Professional Communication in Food Science and Human Nutrition, Graduate Oral Seminar, and Sensory Evaluation of Foods. She has been an academic advisor to at least 40 undergraduates and has supervised research conducted by $4 \mathrm{PhD}, 13$ MS, and 15 undergraduate students. Clark founded the WSU Food Product Development Team in 1998. The team developed more than 25 products with Clark's guidance, 14 of which earned national awards. She currently advises the ISU Food Product Development Team. She coached the WSU Dairy Products Evaluation Team, which earned a dozen national awards at Collegiate Dairy Products Evaluation Competitions, and now coaches the ISU Dairy Products Evaluation Team, which had been inactive for nearly 30 years before her arrival.

Clark is an active member of the Institute of Food Technologists (IFT) and ADSA, where she has served in many service and leadership roles, including chair of the Dairy Foods Division of IFT for two years and section editor in the Dairy Foods section of the Journal of Dairy Science. Clark was honored with the ADSA Foundation Scholar Award for outstanding research and teaching in dairy foods in 2007 and the WSU College of Agricultural, Human and Natural Resource Sciences Individual Integrated Award for excellence in teaching, research, and extension at WSU in 2009.

\section{Citation for Kasey Moyes Recipient of the $\mathbf{2 0 1 0}$ National Milk Producers Federation Richard M. Hoyt Award}

Kasey Moyes, the 2010 recipient of the National Milk Producers Federation Richard M. Hoyt Award, started her academic career at Michigan State Univer-

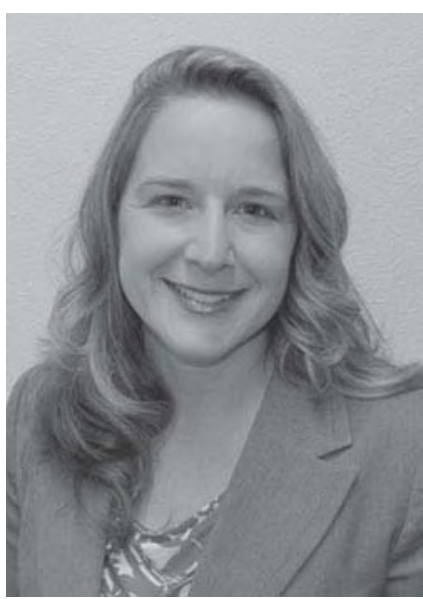
sity, where she received a $\mathrm{BS}$ in animal science in 2001. At Michigan State University, she conducted an undergraduate research project under the advisement of David K. Beede. In 2001, she transferred to the University of Connecticut to work under the advisement of Sheila M. Andrew. Her MS degree involved examining the relationship between negative energy balance (NEB) and risk of mastitis. After completing her MS degree in animal science in 2004, she transferred to the University of Illinois for her $\mathrm{PhD}$ degree in animal science. Her dissertation was a collaborative effort between the University of Illinois and Aarhus University in Tjele, Denmark. Under the coadvisement of James K. Drackley and Juan J. Loor at the University of Illinois, her dissertation examined the effect of dietary-induced NEB on the innate immune response in mid-lactation dairy cows using an

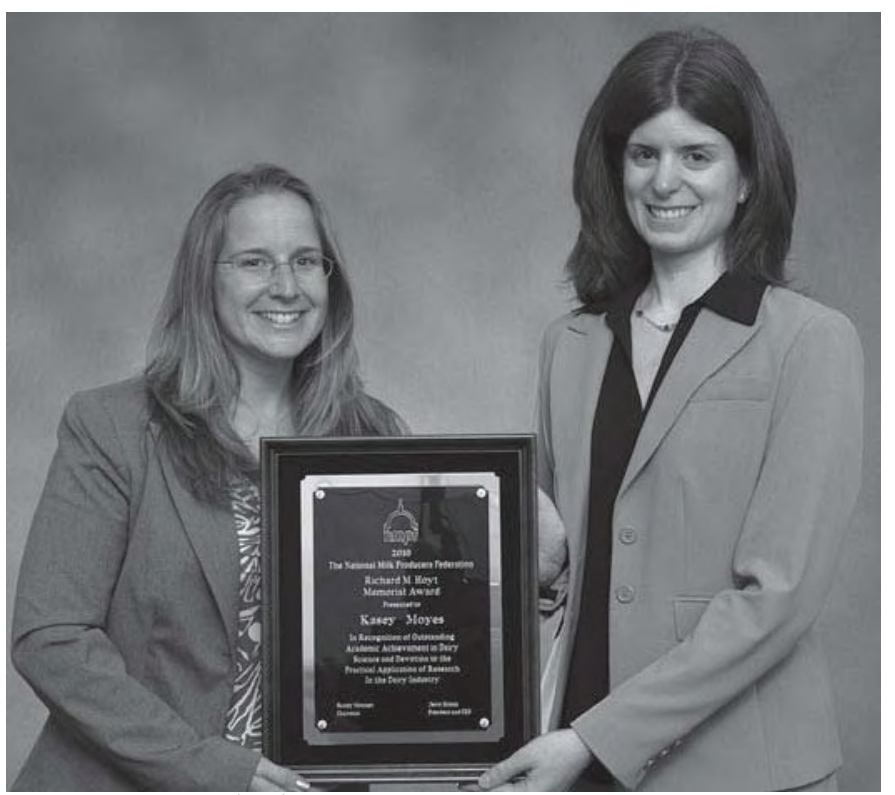

Kasey Moyes (left) receives the 2010 National Milk Producers Federation Richard M. Hoyt Award from Beth Briczinski, donor representative (right). 
intramammary Streptococcus uberis (O140J) mastitis challenge. Dietary-induced NEB in mid-lactation dairy cows has been a useful model that mimics naturally occurring NEB while negating the hormonal and physiological changes that contribute to immunosuppression during the transition period. The innate immune response is the first line of defense against invading organisms and is directly related to acute and chronic inflammation of the mammary gland. Little is known about the genomic-level responses of mammary epithelial cells and blood neutrophils. Using microarray technology and quantitative PCR, this study provided useful information and important insights about early immunologic and metabolic changes that occur in these cell types as well as mechanisms linking peripartal NEB with increased incidence of mastitis. Briefly, results from gene expression analyses indicate relationships between genes associated with immune response (e.g., $T N F A$ ) and those associated with energy metabolism (e.g., PPAR, LPL, and $S C D$ ). Results from these studies provide mechanistic links between postpartal NEB and increased incidence of mastitis. Under the direction of Klaus Lønne Ingvartsen at Aarhus University, Moyes analyzed a unique data set that focused on the relationship between energy status and incidence of mastitis in dairy cattle during early lactation. Results showed that cows with clinical mastitis during early lactation had greater circulating nonesterified fatty acids than did healthy cows before infection, suggesting that severe postpartal NEB may increase mastitis risk. Currently, her research involves the identification of new biomarkers for physiological imbalance and hepatic lipidosis using ITRAQ-based proteomic profiling and clinical-chemical analyses of milk and blood with a goal of describing the practical application and value of the biomarkers.

Kasey Moyes was awarded the National Milk Producers Federation Dairy Leadership Scholarship in 2008, the National Mastitis Council Student Travel Scholarship in 2008, the Mitchell Fellow in Animal Nutrition at the University of Illinois in 2007, the Ayre Study Abroad Fellowship in 2005, the University of Connecticut Graduate Student Fellowship in 2002, and the Michigan State University Graf Program Grant Scholarship in 2000. Moyes has published 13 peer-reviewed articles, 13 abstracts, and 7 extension newsletters.

\section{Citation for Karen Beauchemin \\ Recipient of the $\mathbf{2 0 1 0}$ Nutrition Professionals Inc. Applied Dairy Nutrition Award}

Karen Beauchemin has made outstanding contributions to the dairy industry in the area of rumen function and feed utilization and is truly deserving of this award. She has accomplished this through her research and extension and through the training of postdoctoral fellows and students. Beauchemin is a senior scientist at

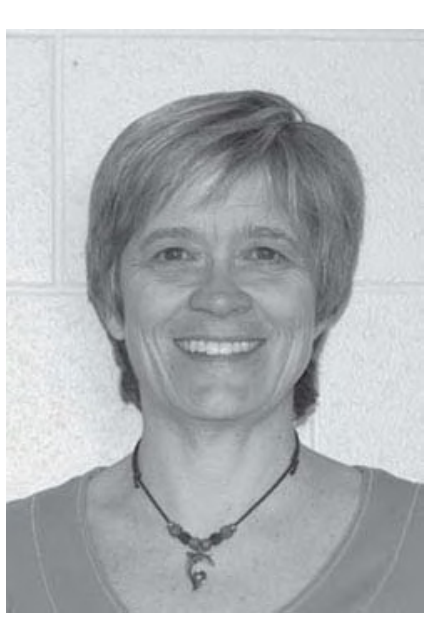
Agriculture and Agri-Food Canada's Lethbridge Research Centre in Alberta. She is also an adjunct professor at three universities in western Canada. Before her career in research, Beauchemin spent several years as a nutritionist with a large feed manufacturer.

Beauchemin has developed a broad-based research program to improve feed utilization of dairy cows. She is recognized internationally for her expertise in the areas of rumen function, acidosis prevention, physically effective fiber, forage utilization, and enteric methane mitigation.

Beauchemin's research in the area of rumen function has led to guidelines that minimize ruminal acidosis in dairy cows while maintaining high levels of milk production. She has studied the dietary factors that contribute to subacute ruminal acidosis, as well as the role of physically effective fiber in stimulating chewing, salivation, and buffering within the rumen. The results from these studies have contributed to dietary fiber rec-

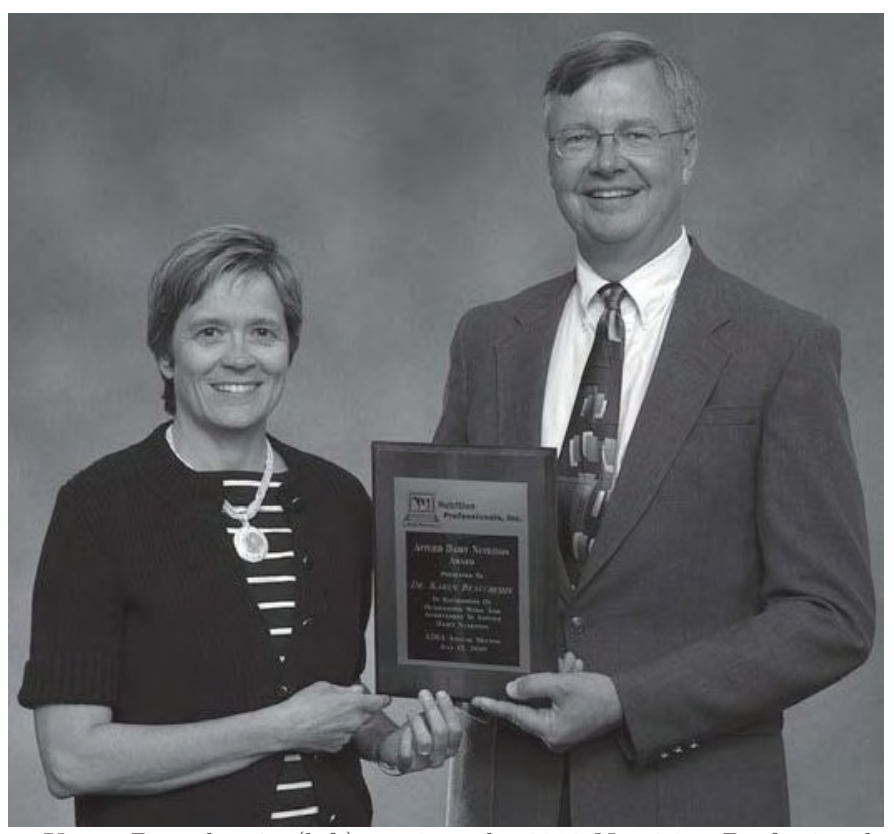

Karen Beauchemin (left) receives the 2010 Nutrition Professionals Inc. Applied Dairy Nutrition Award from Steve Woodford, donor representative (right). 
ommendations for dairy cows. Beauchemin has studied corn- and barley-based diets in combination with a variety of forages. Thus, the results of her research are widely applicable.

Beauchemin is also internationally recognized for her work in the area of feed enzyme technology to improve the utilization of forages by ruminants. The focus of her work has been to identify the mechanisms of action whereby enzymes improve feed digestion, such that feed enzymes that ensure positive and consistent results can be developed for the dairy industry.

In recent years, Beauchemin has extended her research to examine the possibility of modifying dairy cow diets to reduce ammonia and enteric methane emissions. This research is leading to novel nutritional approaches that improve air quality and lessen the environmental footprint of the livestock sector. In addition to curbing greenhouse gas emissions, reducing methane produced during feed digestion also improves the efficiency by which dairy cows convert plant material into milk.

Beauchemin has been an active member of ADSA since 1982. Throughout her career Beauchemin has published a total of 20 book chapters, 16 authoritative reviews, and 166 peer-reviewed scientific papers, with many of these papers published in the Journal of Dairy Science. Beauchemin is an outstanding communicator, particularly in transferring technological findings to producers and nutrition professionals. She has a total of 279 technology-transfer activities including articles in trade journals and presentations to industry. Beauchemin has been an excellent teacher and role model for students and future scientists.

In summary, Karen Beauchemin is truly deserving of the Nutrition Professionals Applied Dairy Nutrition Award because of her outstanding and well-rounded contributions to dairy nutrition research and extension for dairy producers and nutrition professionals.

\section{Citation for Shawn Donkin Recipient of the 2010 Pfizer Animal Health Physiology Award}

Shawn S. Donkin, professor of animal sciences at Purdue University, has developed an internationally recognized research program in the area of nutritional physiology of dairy cattle. This ongoing research is focused on understanding the nutritional, hormonal, environmental, and developmental cues that modulate animal productivity and health. He was born in Truro, Nova Scotia, Canada, where he attended primary and secondary schools before graduating from Cobequid Educational Center in 1978. He then enrolled in Nova Scotia Agricultural College, where he earned an associate's degree in agricultural sciences in 1980 . He continued his education in the Macdonald College of McGill University in Montreal, where he earned a BS degree in general agricultural sciences (with distinction)

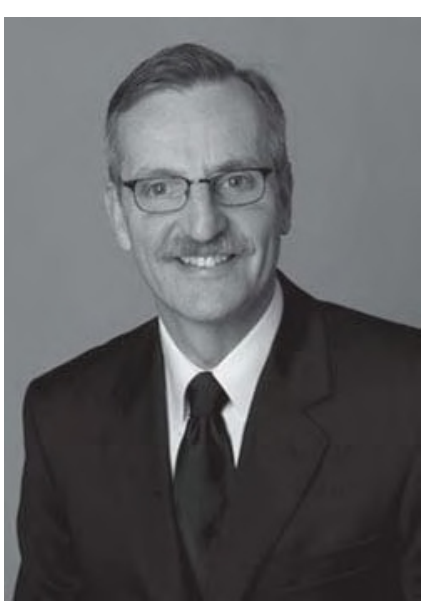
in 1982. He served as a technical field representative, Canada Packers Inc., Shur-Gain Feed Division in Truro, Nova Scotia, from 1982 to 1983. During this period he married Katherine Moreen MacDonald, to whom were subsequently born three children: Ainslie Anne, Hugh Sherman, and Iain Gordon. Between 1983 and 1985, Donkin was a dairy cattle herdsman at Bidalosy Farms Ltd. in Old Barns, Nova Scotia. He then pursued postgraduate studies at The Pennsylvania State University under the direction of G. A. Varga and obtained a MS degree in dairy and animal science in 1987. He then enrolled at the University of Wisconsin-Madison and pursued a $\mathrm{PhD}$ under the direction of L. E. Armentano, finishing in 1992. Donkin was appointed assistant professor in animal sciences at Purdue University in 1995 and was eventually promoted to professor in 2006.

Donkin's research program explores the control of hepatic function that is pertinent to food animal production, animal well-being, and human health. This research, which is both applied and basic in scope, has resulted in feeding recommendations for optimal health and productivity in dairy cattle and has created knowl-

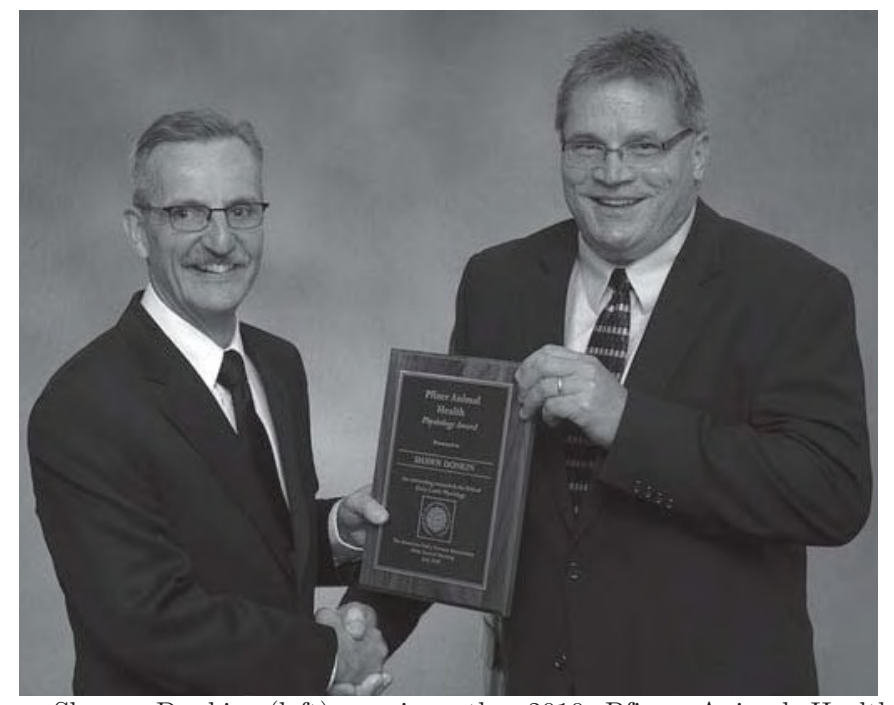

Shawn Donkin (left) receives the 2010 Pfizer Animal Health Physiology Award from Todd Meinert, donor representative (right). 
edge of the underlying biology of nutrient metabolism in mammalian liver. Research conducted in Donkin's laboratory is among the first to describe the molecular events that control glucose and nitrogen metabolism in dairy cattle and developing calves. Ongoing fundamental studies explore the role of physiological transitions and stressors on gene promoter control. Ongoing applied research explores the potential of biofuel coproducts as feeds for ruminants and the effect on animal productivity and health. Donkin has applied his expertise in nutritional physiology to determine the fetal origins of aberrant hepatic glucose and lipid metabolism and relationship to the metabolic syndrome. Additional collaborative research with faculty in the Interdepartmental Nutrition Program at Purdue explores the role of calcium and vitamin D in energy partitioning, cellular metabolism, and insulin signaling.

Donkin has authored 47 refereed publications, 81 abstracts, 13 research reports, and 5 book chapters. He has established collaborations with scientists across the United States and in Israel, Switzerland, Germany, and New Zealand. Donkin's research has been supported by the USDA Cooperative State Research, Education, and Extension Service National Research Initiative, the National Institutes of Health, commodity groups, private industry, state programs, and private foundations. Since 1995, he has secured more than $\$ 6$ million to support his research program at Purdue University.

\section{Citation for Richard Grant Recipient of the 2010 Pioneer Hi-Bred Forage Award}

Rick Grant, president of William H. Miner Agricultural Research Institute in Chazy, New York, is the recipient of the 2010 Pioneer Hi-Bred Forage Award.

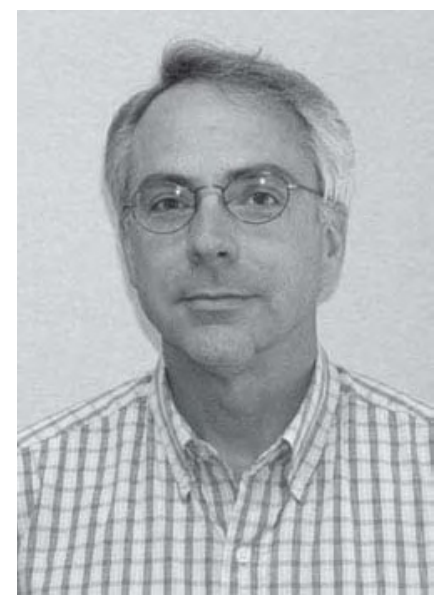

He received his BS in animal science from Cornell University and PhD from Purdue University. From 1990 to 2002, Grant was a faculty member in the Department of Animal Science at the University of Nebraska-Lincoln. Since 2003, he has served as president of Miner Institute, which focuses on the interactions between forages, animal nutrition and management, and the environment. Grant's interest in forages began with his doctoral research, which evaluated the effect of forage particle length on dairy cattle metabolism and milk fat depression. Since then, nearly $70 \%$ of his published research has focused on improving forage use by dairy cattle.

While at the University of Nebraska, Grant began evaluating the use of brown midrib sorghums and other high-fiber digestibility forages for lactating dairy cattle. The research group demonstrated that brown midrib sorghum crops compete well with corn silage in lactation diets and showed that not all brown midrib mutants are similar in their nutritive value. To date, this research has resulted in 14 peer-reviewed publications. Grant has also conducted research that demonstrated the importance of the interaction between forage and nonforage sources of fiber when feeding byproduct-based diets to dairy cattle. Since coming to Miner Institute, Grant has had the opportunity to lead a research group that is focused on improving methods of forage analysis. The group developed a particle-sizing tool called the Z-Box for on-farm measurement of the physical effectiveness of forage sources. This tool has been used in the dairy industry to generate effectiveness factors for use in ration formulation and is in use in North America, Europe, and Asia. The Miner research group has also assessed ways to improve the physically effective fiber system by defining the relationships between forage particle size, fiber digestibility, and fragility.

Grant has authored or coauthored hundreds of articles for peer-reviewed journals, conference proceedings, and popular press. He has given over 200 invited presentations in the United States and seven other countries. Grant has supervised 28 graduate students during his career at Nebraska and Miner Institute. In addition to research and education, Grant has served ADSA as an editor for the Journal of Dairy Science, president of the Midwest Branch of ADSA, chair of the Production

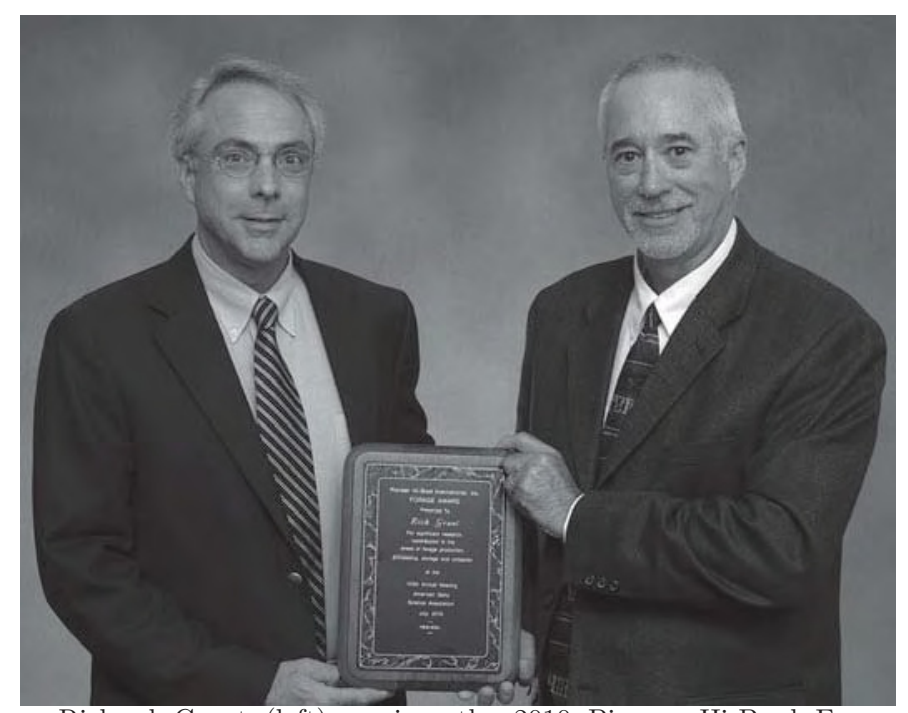

Richard Grant (left) receives the 2010 Pioneer Hi-Bred Forage Award from Bill Mahanna, donor representative (right). 
Division, and overall program-planning chair for the annual meeting. Grant is also a past president of the Feed Analysis Consortium.

Grant's active research and educational programs have had a positive effect on the effective use of forage by the dairy industry.

\section{Citation for Sheila Andrew Recipient of the 2010 West Agro Inc. Award}

Sheila Andrew has used her unique background as a nutritional scientist and FDA regulator to build a productive milk quality research and extension

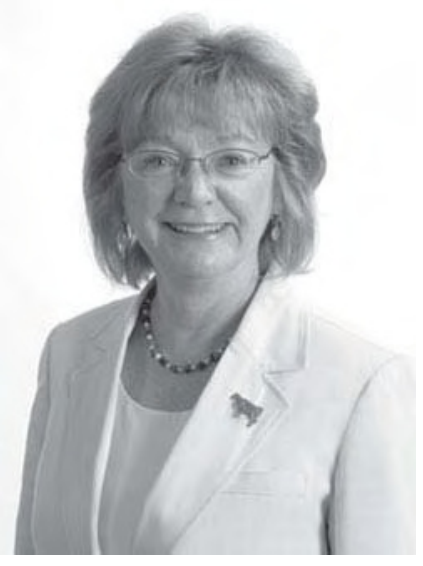
program. This year's winner of the 2010 West Agro Inc. Award has produced significant and practical outcomes in at least three major areas related to udder health. Her effective integration of research and extension has allowed her to rapidly translate research results into practical farm practices, and she has affected a broad community of udder health professionals by assuming a leadership role in the National Mastitis Council.

Andrew has been active in a variety of important areas related to milk quality and mastitis control. The viability of the dairy industry is predicated on producing milk that is free of contaminants such as antibiotic residues. Andrew has been a leader in identifying factors affecting detection of antibiotic residues and determining the effect of mastitis control practices on the risk for antibiotic residues in milk. Her work has included evaluation of accuracy of residue screening tests, factors affecting risk of false positive antibiotic residue screening tests, and programs to reduce the risk of residues. She has published eight scientific publications and several extension bulletins regarding antibiotic residues and has presented her work at many industry events. Andrew is considered an expert in this area, and she addresses requests in this area from across the United States. Her work has helped farmers and industry professionals understand the limitations of residue tests and the importance of implementation of mastitis control programs that minimize risks to human food safety.

Andrew has used her background as a nutritional researcher to explore the relationship between mastitis and energy status. Her work on this subject has

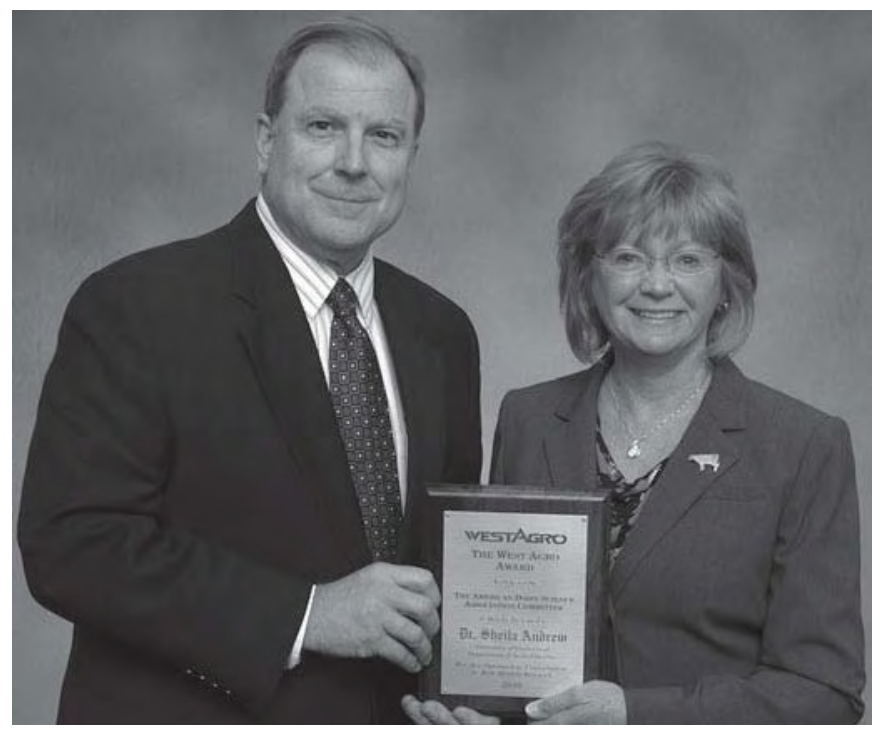

Sheila Andrew (right) receives the 2010 West Agro Inc. Award from Wyatt Smith, donor representative (left).

indicated that the risk for subclinical mastitis in the postpartum period is increased for cows with excessive body condition during the previous dry period and a greater loss of body condition. Her research has shown that these changes are related to alterations in plasma $\beta$-carotene and $\alpha$-tocopherol concentrations and has indicated that energy status of the prepartum cow is related to a risk for mastitis in the subsequent lactation.

Andrew is known as a team player and has been an effective collaborator on several projects that have focused on evaluation of novel products for preventing and treating mastitis. She has published research focused on evaluation of plant-derived antimicrobials and is actively pursuing research on innovative products that can aid in teat disinfection and reduction in exposure to environmental pathogens in animal housing areas. The results from this area of research over the past five years have resulted in three refereed journal papers, one $\mathrm{PhD}$ dissertation, three MS theses, five extension factsheets, and two seminars and workshops.

In summary, Andrew has been a productive researcher, an effective mentor to several graduate students, and an active extension specialist in the area of mastitis control and milk quality. She is a qualified recipient of this year's West Agro Award.

\section{Citation for Luis G. D. Mendonca Recipient of the 2010 National Milk Producers Federation Graduate Student Paper Presentation Contest in Dairy Production, MS division}

Luis G. D. Mendonca, of the University of Minnesota, is the first place winner of the 2010 National Milk 


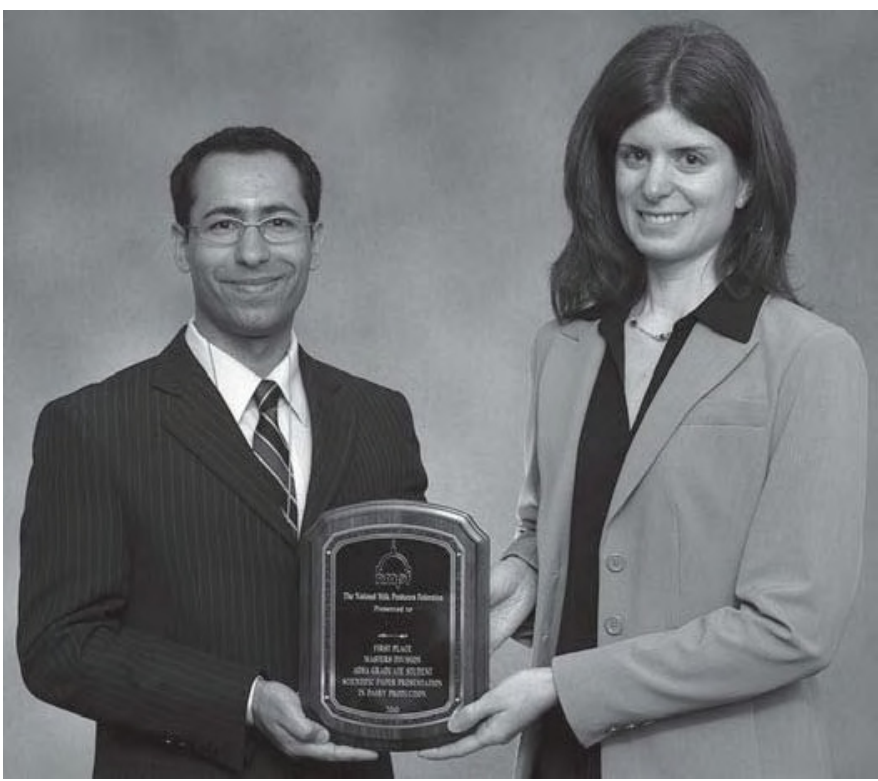

Luis Mendonca (left) receives the 2010 National Milk Producers Federation Graduate Student Paper Presentation Contest in Dairy Production (MS division) from Beth Briczinski, donor representative (right).

Producers Federation Graduate Student Paper Presentation Contest in Dairy Production (MS division). Luís has a DVM degree from the Maringá State University in Brazil. Currently he is in a combined program that includes a residency in dairy production medicine and an MS at the University of Minnesota under the direction of Ricardo Chebel. His ongoing research focuses on the comparison of prepartum and postpartum immune function and postpartum uterine health between Holstein and crossbred lactating dairy cows.

Hugo Ramirez Ramirez of the University of Nebraska-Lincoln placed second and Anne H. Laarman of the University of Alberta placed third in the competition.

\section{Citation for Claire Windeyer \\ Recipient of the 2010 National Milk Producers Federation Graduate Student Paper Presentation Contest in Dairy Production, PhD division}

Claire Windeyer, of Ontario Veterinary College, was the first place winner of the 2010 National Milk Producers Federation Graduate Student Paper Presentation Contest in Dairy Production (PhD Division).

Xavier Revelo of the University of Missouri placed second and Yapa Wickramasinghe of the University of California-Davis placed third in the competition.

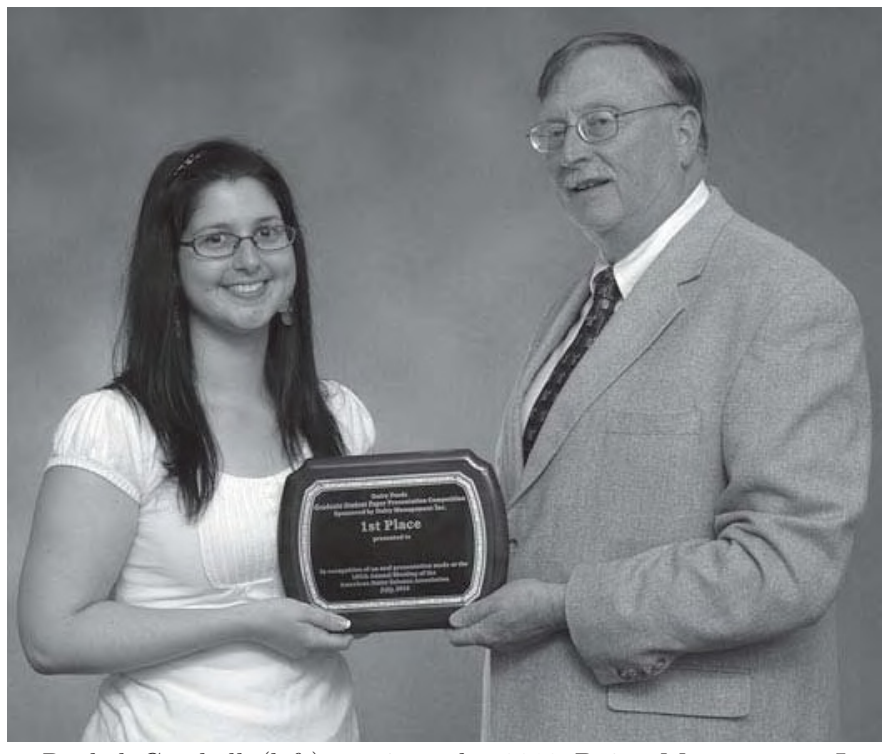

Rachel Cambell (left) receives the 2010 Dairy Management Inc Graduate Student Paper Presentation Contest in Dairy Foods Research from Dave McCoy, donor representative (right).

\section{Citation for Rachel Cambell \\ Recipient of the 2010 Dairy Management Inc. Graduate Student Paper Presentation Contest in Dairy Foods}

Rachel Cambell, of North Carolina State University, was the first place winner of the 2010 Dairy Management Inc. Graduate Student Paper Presentation Contest in Dairy Foods. Rachel grew up in Chapel Hill, North Carolina, and then moved to Raleigh, North Carolina, to attend NC State for her undergrad degree. She graduated in May 2008 with a BS in food science and technology. In the fall, she began her work on her MS degree in sensory science and flavor chemistry under MaryAnne Drake at NC State University. Rachel anticipates graduating in December 2010, and she plans to continue her $\mathrm{PhD}$ under the guidance of MaryAnne Drake at NC State.

Prashanti Kethireddipalli of the University of Guelph placed second and Gagan Deep of South Dakota State University placed third in the competition.

\section{Citation for Anne Sauer Recipient of the 2010 Leprino Foods Graduate Student Poster Presentation Contest in Dairy Foods Research}

Anne Sauer, of Cornell University, was the first place winner of the 2010 Leprino Foods Graduate Student 


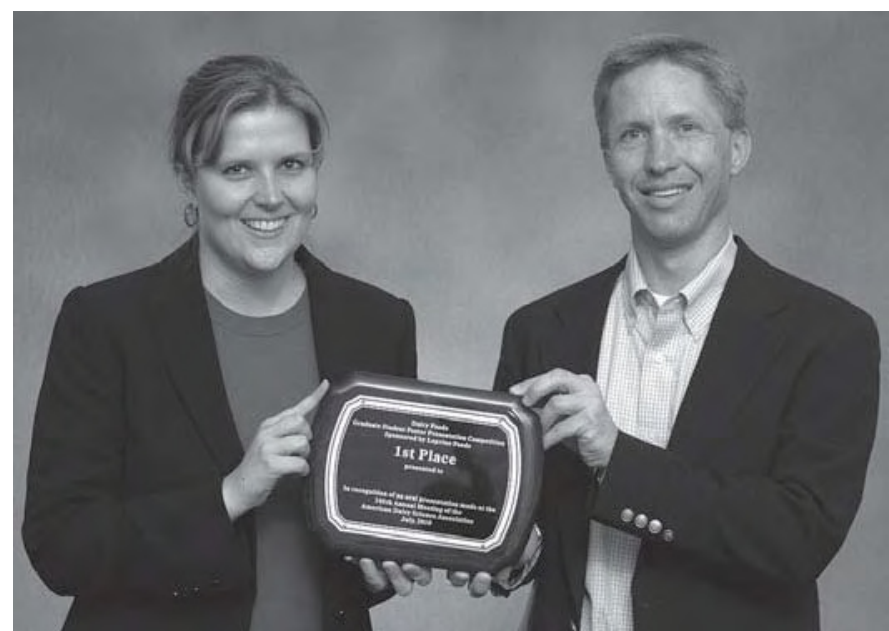

Anne Sauer (left) receives the 2010 Leprino Foods Graduate Student Poster Presentation Contest in Dairy Foods Research from Richard Merrill, donor representative (right).

Poster Presentation Contest in Dairy Foods Research. Anne completed her BS and MS degrees in food technology from Berlin University of Technology, Germany. Anne is currently pursuing her $\mathrm{PhD}$ in food science at Cornell University. Anne has done internships at the Johnson Graduate School of Management, Ithaca, New York, and at Unilever Deutschland GmbH, in Heilbronn, Germany. Anne is a student representative of the Non-thermal Processing Division in IFT and treasurer of the Cornell Food Science Club. Anne is a recipient of the IFT Foundation Graduate Student scholarship 2010-2011 and the International Dairy Foods Association Dairy Industry Graduate Scholarship 2010.

Oliver Janevski of South Dakota State University placed second and Maria Angelica Listiyani of North Carolina State University placed third in the competition.

\section{Citation for Christina Williams \\ Recipient of the 2010 Land O'Lakes, Purina Feed LLC Graduate Student Poster Contest in Dairy Production, MS division}

Christina Williams, of Utah State University, was the first place winner of the 2010 Land O'Lakes, Purina Feed LLC Graduate Student Poster Contest in Dairy Production (MS division). Christina has a BS degree in animal science from Colorado State University and has worked as a microbiologist at the Centers for Disease Control in Fort Collins. Christina is currently completing her MS degree in dairy science at Utah State University under the direction of Jong-Su Eun. Christina's MS thesis is on the effects of different sources of condensed tannins on ruminal metabolism in continuous culture.

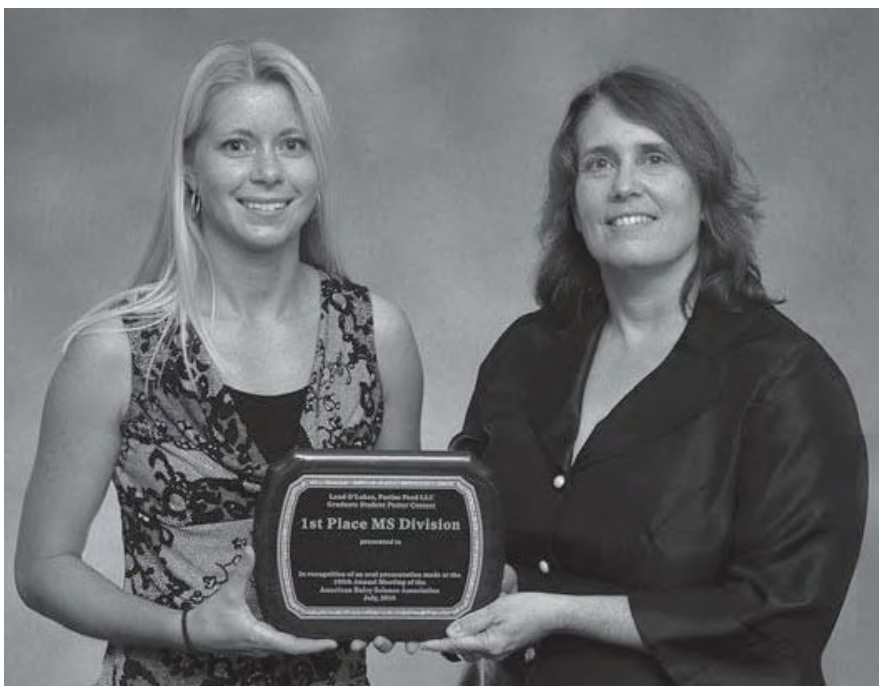

Christina Williams (left) receives the 2010 Land O'Lakes, Purina Feed LLC Graduate Student Poster Contest in Dairy Production (MS division) from Cindie Luhman, donor representative (right).

Jessica Graves of Mississippi State University placed second, and Fernanda Lopes of the University of Wisconsin-Madison placed third in the competition.

\section{Citation for Julio Giordano \\ Recipient of the 2010 Land O'Lakes, Purina Feed \\ LLC Graduate Student Poster Contest in Dairy Production, PhD division}

Julio Giordano, of the University of WisconsinMadison, was the first-place winner of the 2010 Land O'Lakes, Purina Feed LLC Graduate Student Poster Contest in Dairy Production (PhD division). Julio

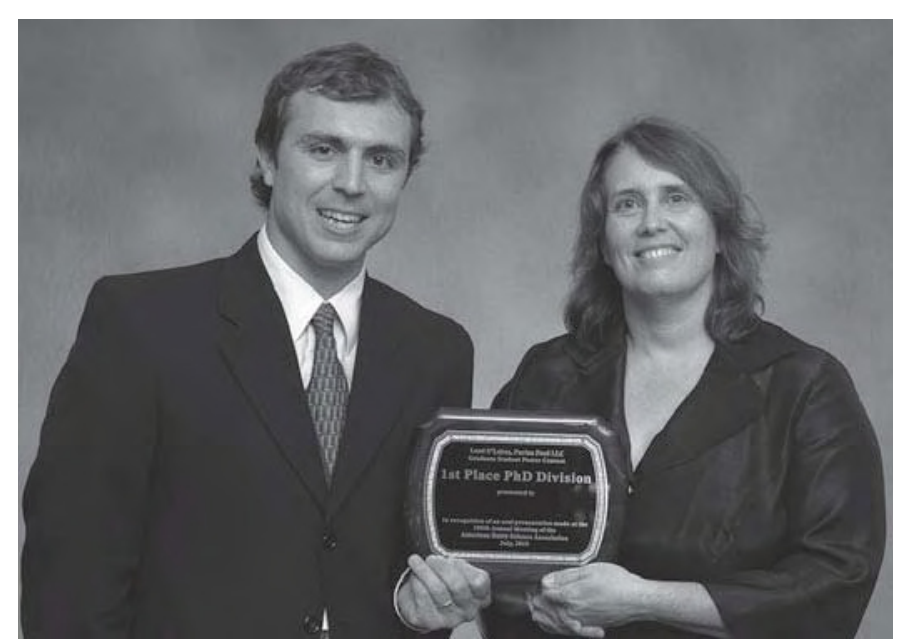

Julio Giordano (left) receives the 2010 Land O'Lakes, Purina Feed LLC Graduate Student Poster Contest in Dairy Production (PhD division) from Cindie Luhman, donor representative (right). 
has an MS degree in reproductive physiology from the University of Tennessee and a DVM degree from the Catholic University of Cordoba in Argentina. Julio is currently a $\mathrm{PhD}$ student of reproductive physiology at the University of Wisconsin, working under the direction of Paul Fricke. His current research interests are optimization of systematic synchronization strategies, hormone dynamics during pregnancy loss, and development of simulation models for economics of reproductive efficiency in dairy cows.

Katie Schoenberg of Cornell University placed second, and Felipe Cardoso of the University of Illinois placed third in the competition.

\section{Citation for Kaleena Westaby Recipient of the 2010 Genevieve Christen Undergraduate Student Award}

Kaleena Westaby is an extraordinary individual with a strong desire to further the dairy industry. Westaby has been involved in the dairy industry as long as she

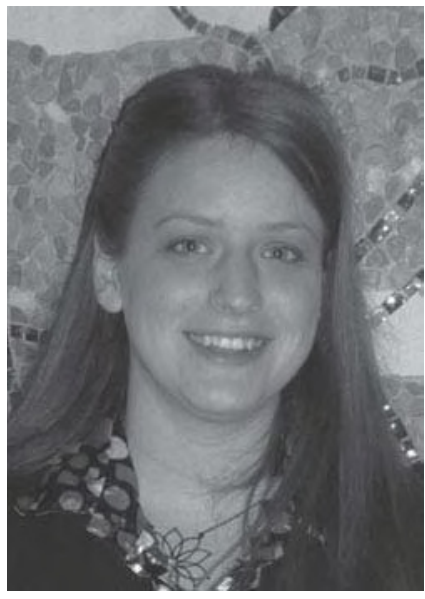
can remember. She spent much of her youth in the barn, naming calves and helping her father with chores. Her father kept a small brown book that contained 25 years of herd lineage. By age 14, Westaby had mostly memorized the entire book and had realized her passion for dairy genetics. Westaby is a recent graduate of Iowa State University (ISU), where she graduated magna cum laude with a BS in dairy science. At ISU, Westaby served as the 2009 vice president of the Dairy Science Club, a role in which she appointed and coordinated all club activities, which was no easy task. Westaby has also served as the 2009 Midwest regional officer-at-large of the Midwest Regional ADSA Student Affiliate Division. In addition to her responsibilities in the Student Affiliate Division and local club, Westaby has been a member of the ISU College of Agriculture and Life Sciences Honors Program and student council, Cardinal Key, and Phi Kappa Phi. She is also a National Dairy Shrine Lifetime Member. Westaby has participated on the ISU Dairy Judging Team and Dairy Challenge Team. Westaby has been one of the most dedicated volunteers with the ISU Dairy Science Club's monthly involvement in the Food at First program. The ISU Dairy Science Club is the only campus-based group that volunteers each

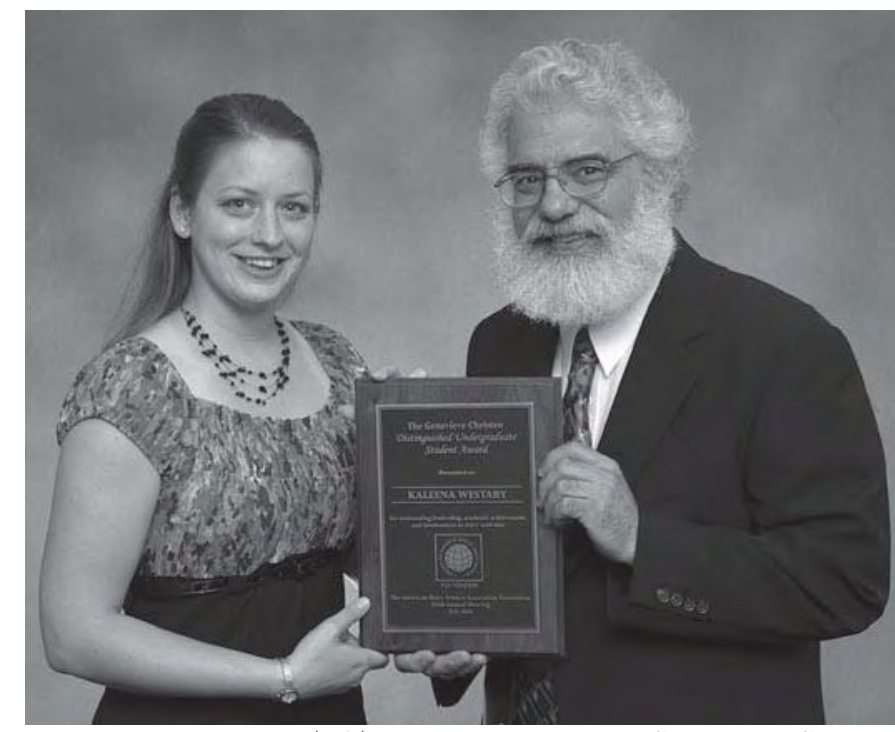

Kaleena Westaby (left) receives the 2010 Genevieve Christen Undergraduate Student Award from Dave Barbano, ADSA Foundation Chair (right).

month for a soup kitchen program where community members plan, prepare, serve, and clean up after meals offered seven days per week. To prepare her further for her career, Westaby has spent two summers interning for ABS Global, where she has created and developed training and marketing materials, run the computer mating program, and summarized and reported field trial results. It was through her time there that she discovered the value of research within AI companies. In addition to starting a career in the dairy industry, Westaby plans to stay involved with youth judging teams and 4-H. Westaby plans to travel to England and Scotland this summer to learn perspectives on farm animal welfare in those countries so she can be more involved in similar emerging issues in the United States. She feels one of the most beneficial things she can do is to help mentor the next generation of dairy leaders. Westaby exemplifies the leadership, service, and dedication to the dairy industry that the Genevieve Christen Award represents. She is greatly honored by receiving the 2010 Genevieve Christen Distinguished Undergraduate Student Award.

\section{Citation for Federico Harte Recipient of the 2010 ADSA Foundation Scholar Award in Dairy Foods}

The recipient of the 2010 ADSA Foundation Scholar Award, Dairy Foods Division, is Federico Harte, assistant professor in the Department of Food Science and Technology at the University of Tennessee, Knoxville. Harte earned his BS in agricultural engineering at the University of Uruguay in 1995 and his PhD in 
engineering sciences from the Program in Food Engineering, Department of Biological Systems Engineering at Washington State University in 2002. Following

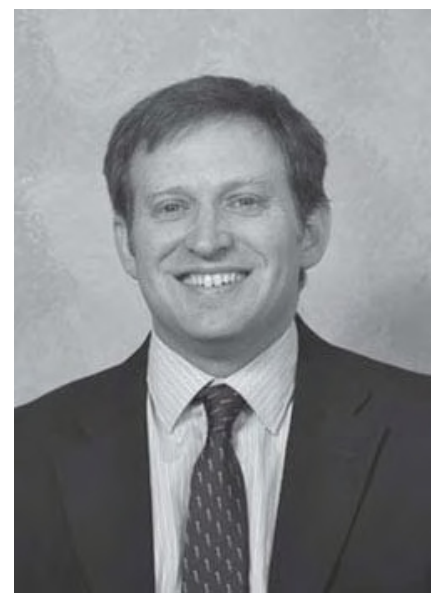
positions as a lecturer and assistant professor in Uruguay, Harte was appointed assistant professor at the University of Tennessee in 2005.

During the past five years, Harte has established a highly productive and innovative research program in dairy foods engineering at the University of Tennessee. His research program has focused on four major areas: (1) the use of high-pressure homogenization in yogurt and cheese manufacturing; (2) the use of nonthermal technologies for novel functional applications of milk proteins, with emphasis on the casein micelle as a delivery system for hydrophobic nutraceuticals; (3) novel nanostructure-rheology properties of macromolecules derived from milk proteinpolysaccharide interactions; and (4) the casein micelle nanostructure and function. Harte has compiled a prolific publication record. He has 32 peer-reviewed journal papers, 6 book chapters, and numerous abstracts and proceedings papers from professional conferences. He has filed six total patent disclosures through The University of Tennessee Research Foundation and has one provisional patent application.

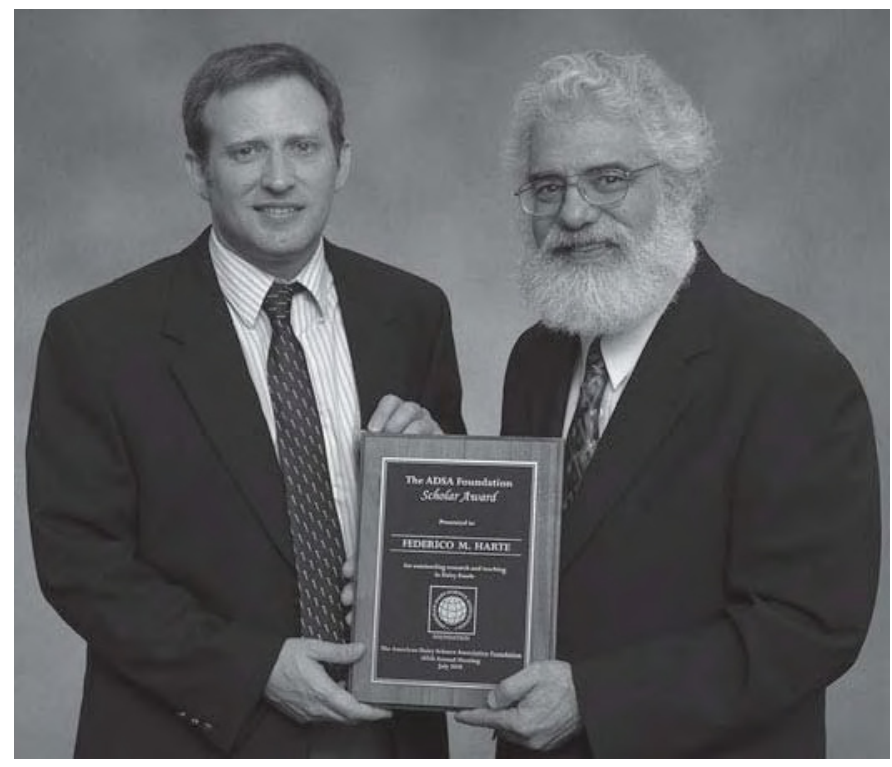

Federico Harte (left) receives the 2010 ADSA Foundation Scholar Award in Dairy Foods from Dave Barbano, ADSA Foundation Chair (right).
In addition to being a highly prolific researcher, Harte is dedicated to passing the baton of knowledge through his teaching. He teaches an intermediate-level undergraduate course in Food Engineering and a graduatelevel course in Advanced Food Polymers. He clearly brings passion to his teaching philosophies and receives excellent feedback from students.

Harte and his research group are frequent contributors to professional conferences. During the past five years, he has been an invited speaker at the Institute of Food Technologists Annual Meeting (multiple times); the Conference of Food Engineering; the National Meeting of the American Chemical Society; the Annual Meeting of the International Association for Food Protection; the International Conference of Engineering and Food; the Minorities in Agriculture, Natural Resources, and Related Sciences-Innovation, Exploration, and Discovery Conference; and other international meetings in Spain, Uruguay, Italy, and Chile. Clearly, these efforts reinforce the highly visible and international presence of his program.

\section{Citation for Kenneth Kalscheur Recipient of the 2010 ADSA Foundation Scholar Award in Production}

The recipient of the 2010 ADSA Foundation Scholar Award, Production Division, is Kenneth Kalscheur, associate professor in the Department of Dairy Science

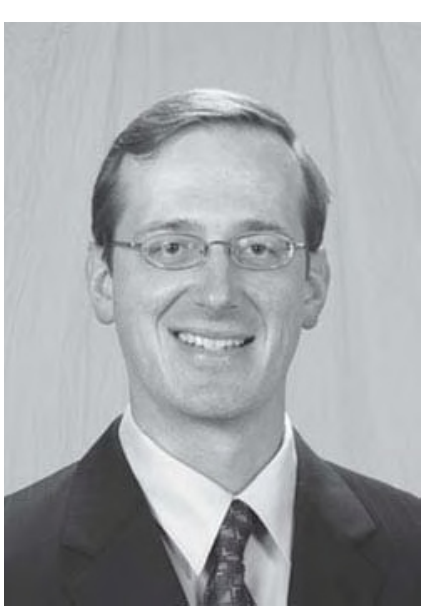
at South Dakota State University, Brookings. Kalscheur earned his BS in dairy science from the University of WisconsinMadison and his MS and $\mathrm{PhD}$ in animal sciences from the University of Maryland. Kalscheur was appointed assistant professor at South Dakota State in 2001 and was promoted to associate professor in 2006. In addition, he served as exchange professor in the Department of

Dairy Science at Chungnam National University in Daejeon, South Korea, during the spring of 2007.

Kalscheur has become one of the world's leading authorities on the use of distillers coproducts in diets for dairy cattle. Key areas of focus within his research have been (1) to determine both the limits and practical inclusion rates in diets of distillers grains with solubles produced during ethanol production; (2) to evaluate factors affecting the relationships of feeding distillers 


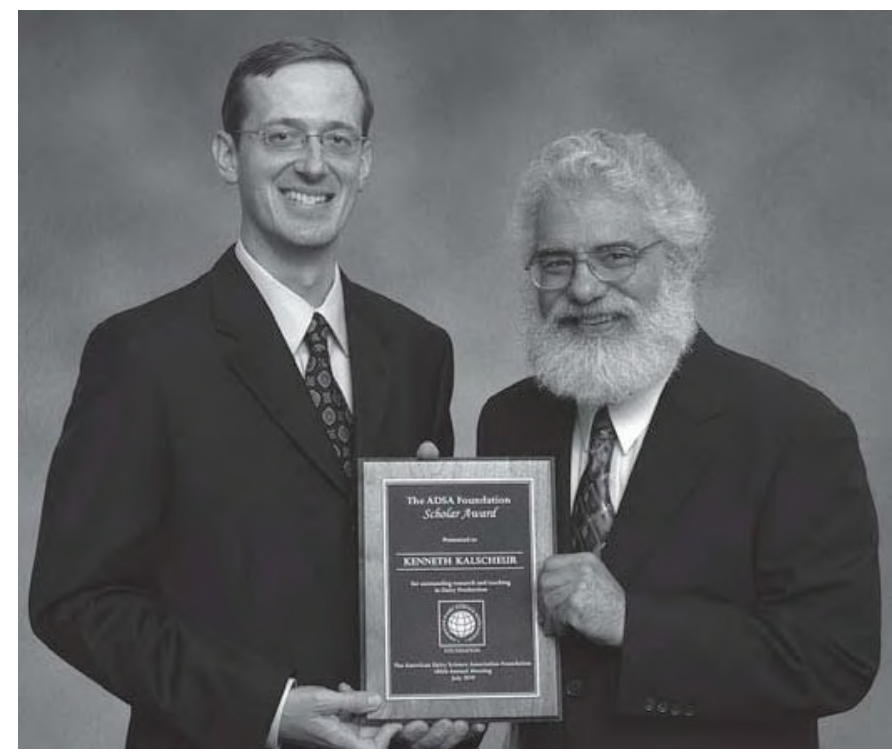

Kenneth Kalscheur (left) receives the 2010 ADSA Foundation Scholar Award in Dairy Production from Dave Barbano, ADSA Foundation Chair (right).

grains with solubles on milk fat production; (3) to study utilization of protein, amino acids, and phosphorus from distillers grains; and (4) to explore the use of blended feed products using distillers grains. These areas of research have led to substantial scientific productivity, as evidenced by a total of 39 peer-reviewed journal papers, 85 abstracts at scientific meetings, and 6 conference proceedings. In addition, Kalscheur has authored or coauthored 26 extension publications and 23 articles in the popular press. He has served as graduate committee chair for five completed MS students and two completed $\mathrm{PhD}$ students and currently is committee chair for two PhD students and one MS student. To date, he has secured external research funding of nearly $\$ 900,000$ as principal investigator and $\$ 1.5$ million as a co-investigator.

In addition to his highly productive research program, Kalscheur actively contributes to the undergraduate and graduate teaching programs at South Dakota State. He teaches the introductory course in dairy science, the dairy farm management course, and the dairy cattle feeding course for undergraduates and a graduate-level course in ruminology. He serves as advisor to the South Dakota State University Dairy Club.

Furthermore, it is clear that Kalscheur recognizes the importance of translating his work into practice. As mentioned earlier, he has authored or coauthored numerous extension publications and popular press articles along with speaking at a number of industry conferences and programs across North America and in Japan, China, and Korea.

\section{Citation for Gary Hartnell Recipient of the 2010 ADSA Award of Honor}

Gary F. Hartnell was raised on a general livestock farm near Salem, Wisconsin. He received his BS degree (1973) in chemistry from the University of Wisconsin-

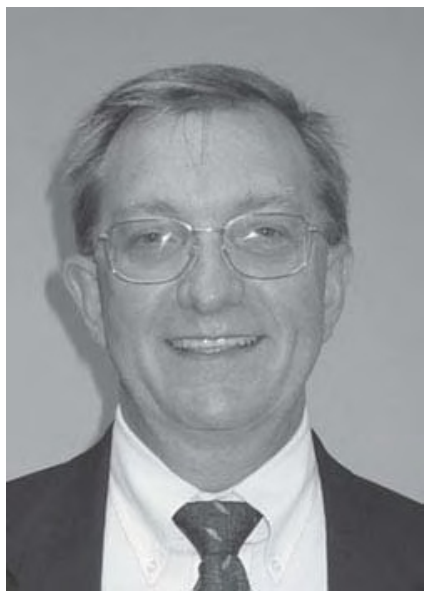

Parkside. His MS degree (1975) and $\mathrm{PhD}$ degree (1977) were completed at the University of Wisconsin-Madison. His doctorate degree was in dairy science with minors in biochemistry and bacteriology. From 1977 through 1983, Hartnell worked for Wayne's Feed Division of Continental Grain Company, where he led the dairy and beef research and technical service efforts. From 1983 to the present,

Hartnell has been employed by Monsanto Company, St. Louis, Missouri, as an animal nutritionist and has been actively involved in biotechnology. During this time he has successfully orchestrated research worldwide encompassing (1) nutrition studies with poultry, livestock, and aquaculture fed genetically modified crops or coproducts derived from them; (2) studies pertaining to milk quality and milk manufacturing characteristics and clinical efficacy trials pertaining to bovine somatotropin; and (3) studies evaluating grain and forage

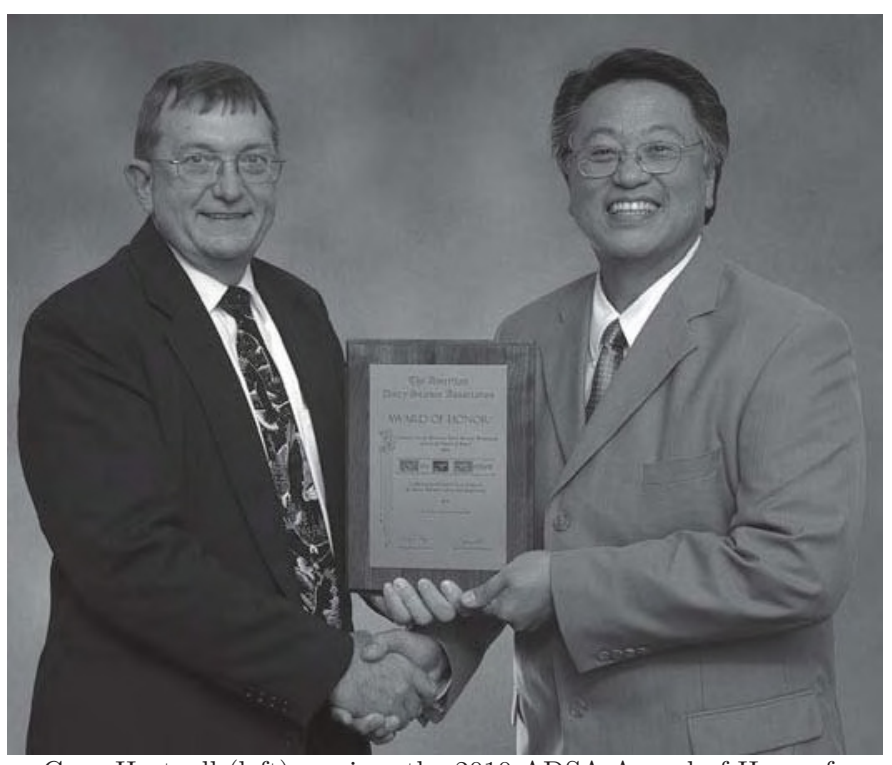

Gary Hartnell (left) receives the 2010 ADSA Award of Honor from Phil Tong, ADSA President (right). 
characteristics benefiting various species of animals. As a senior fellow with Monsanto, Hartnell develops strategies based on science for the acceptance of biotech crops and their coproducts and conducts poultry, livestock, and aquaculture studies in the evaluation of these products for regulatory, industry, and consumer acceptance globally.

As a member of ADSA since 1973, Hartnell has served ADSA as a member of numerous committees such as feeding and management, international, awards, strategic planning, nomination, and membership. He served in key leadership roles in the production division. He participated in the ADSA Foundation auction. He has been a member of the board of directors, vice president, president, past president, and past past president. He represented ADSA on the FASS board, where he served as president and past president. Hartnell has served as ADSA's representative to the European Association of Animal Production (EAAP) and to the FASS Scientific Policy Committee, which he chaired. He was instrumental in establishing ADSA's strategic planning process and was a strong advocate for ADSA's role as an international organization. He helped establish speaker exchanges between ADSA and the British Society of Animal Science and EAAP. He leverages ADSA's strengths with other international societies to address issues affecting its members globally. He helped ADSA become more actively involved in scientific and public policy through relationships with like-minded dairy foods, processing, and production organizations.

Hartnell is a member of the American Society of Animal Science, ADSA, Poultry Science Association, World Aquaculture Society, American Registry of Professional Animal Scientists, Dairy Shrine, The Academy of Science of St. Louis, Sigma Xi, and Federation of Animal Science Societies (past president). He currently serves on the National Research Council's Board of Agriculture and Natural Resources, which resides in the National Academy of Science. He has given presentations at nutrition conferences, feed industry conferences, scientific forums, and producer and commodity group events in Asia, Europe, Africa, South America, and North America. He has authored or coauthored over 100 abstracts; 71 scientific journal articles; 9 book chapters; and 121 popular press, symposia, and conference articles.

Hartnell is blessed to have his wife, Kathy, four children, and six grandchildren.

\section{Citation for Roger Natzke Recipient of the 2010 ADSA Distinguished Service Award}

Roger P. Natzke is professor emeritus and past chairman of the Department of Dairy Science at the University of Florida. Throughout his career, Natzke has

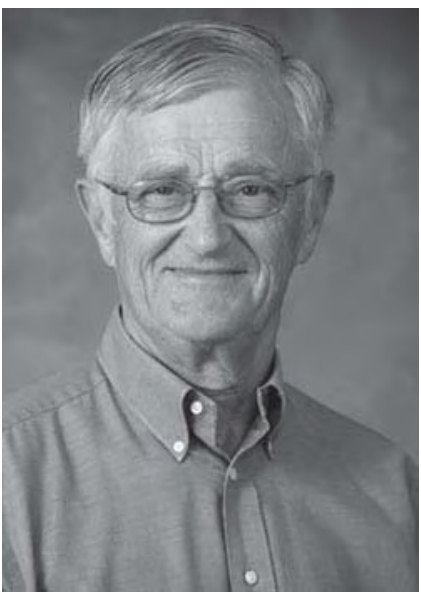
demonstrated a flair for visionary thinking and the skills and energy to realize that vision. His efforts have had, and will continue to have, a far-reaching effect on the dairy industry. Natzke's actions to create a partnership with the Florida dairy industry can serve as a model for effective industry-university teamwork. An important innovation was the formation of the Dairy Advisory Committee, where farmers came to Gainesville twice a year to talk to faculty. In response to producer needs, Natzke moved aggressively to establish a Dairy Business program at Florida that has served as a national model. The spirit of partnership between the industry and university culminated in the

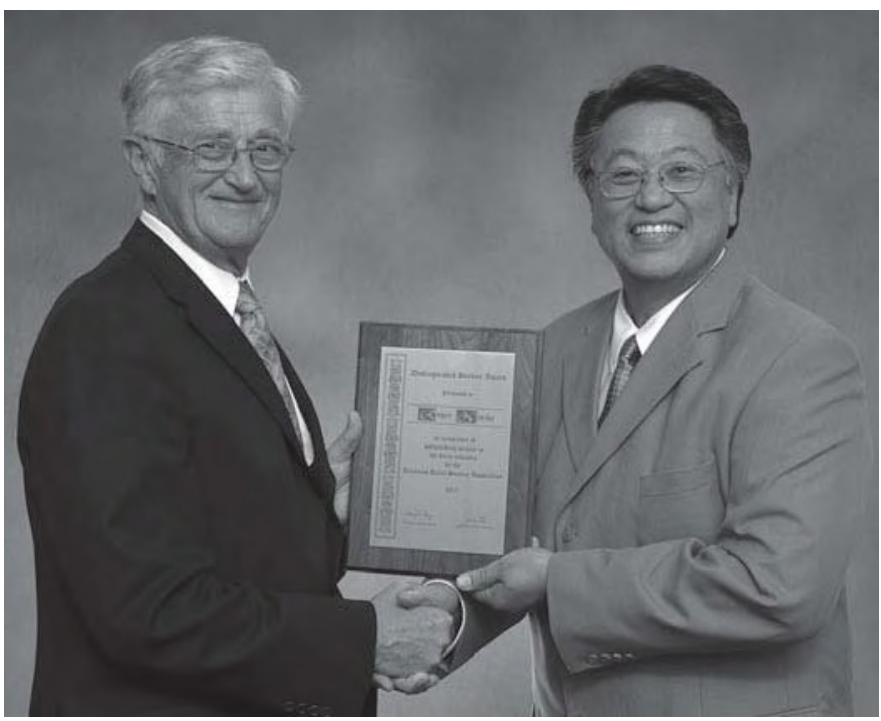

Roger Natzke (left) receives the 2010 ADSA Distinguished Service Award from Phil Tong, ADSA President (right). 
formation of the Florida Milk Checkoff Program, where dairy farmers use a small portion (one penny per $100 \mathrm{lb}$ of milk) of milk income to support research, teaching, or extension projects. Decisions about project funding are made by dairy farmers. To date more than $\$ 6,000,000$ has been distributed. Nationally, Natzke led efforts with FAIR '95 to bring forward industry priorities for research, teaching, and extension to congress. He was also a key leader in the formation of FASS and later served as a member of the FASS board, vice president, and president. Natzke has also served on the board of directors of the National Mastitis Council. Finally, it should be pointed out that Natzke was one of the first leaders in dairy science to call for regionalization of efforts, beginning in the 1980s. His presence on the national scene as an advocate for regionalization is undoubtedly one of the reasons why regionalization plans started much more recently have come to fruition. 